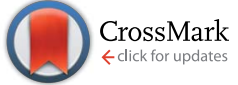

Cite this: RSC Adv., 2016, 6, 78803
Received 4th June 2016

Accepted 5th August 2016

DOI: $10.1039 / c 6 r a 14508 f$

www.rsc.org/advances

\section{Deciphering of polycationic carbohydrate based non-viral gene delivery agents by ESI-LTQ-Orbitrap using CID/HCD pairwise tandem mass spectrometry $\dagger$}

\author{
Cédric Przybylski, $t^{* a}$ Juan M. Benito, ${ }^{b}$ Véronique Bonnet, ${ }^{d}$ Carmen Ortiz Mellet ${ }^{c}$ \\ and José M. García Fernández ${ }^{b}$
}

\begin{abstract}
For almost three decades, gene therapy has been gaining interest to efficiently treat some severe diseases. In such context, the discovery of an efficient non-viral gene carrier to deliver genetic material into targeted cell nuclei is of prime importance. Numerous synthetic vectors that have been designed exhibit high transfection efficiency but also suffer from extensive cytotoxicity, thus justifying efforts to synthesize more bio-compatible ones, for example, with carbohydrate scaffolds. In this sense, cyclodextrins (CDs) are well known to present low to very low cytotoxicity in humans and have potential, after polycationization, to serve as suitable compaction/transfection agents for RNA/DNA. However, such polycationic CDs must be accurately characterized to establish a straightforward structure-biological activity relationship which is guided by the nitrogen/phosphorus ratio (N/P). In the study herein, we demonstrated that electrospray-(tandem) mass spectrometry (ESI-(MS)MS) combining Collision Induced Dissociation (CID) and Higher Collision induced Dissociation (HCD) is a useful tool for such synthetic agent characterization. The suitability of $\mathrm{CID} / \mathrm{HCD}$ pairwise combination was investigated for the structural deciphering of five representative members of a polycationic cyclodextrin library. Our approach allows for easy access to content, type and localisation of amino groups thereby offering a useful tool to correlate the synthetic delivery agent with effective compaction of oligo-/polynucleotides.
\end{abstract}

\section{Introduction}

Nowadays, a number of therapeutic strategies rely on crossing biological barriers to deliver active drugs directly to the target cells. In some cases, such as during gene therapy, the success of the clinical assay is highly dependent of efficient and safe delivery systems. This issue was soon recognized and still remains a challenge for the past three decades. Due to their natural ability to infect cells, viruses (viral capsids), after oriented modification of their genome, represent attractive

${ }^{a}$ Université d'Evry-Val-d'Essonne, Laboratoire Analyse et Modélisation pour la Biologie et l'Environnement, CNRS UMR 8587, Bâtiment Maupertuis, Bld F. Mitterrand, F-91025 Evry, France. E-mail: cedric.przybylski@upmc.fr

${ }^{b}$ Instituto de Investigaciones Quimicas (IIQ), CSIC - Universidad de Sevilla, Américo Vespucio 49, Isla de la Cartuja, E-41092 Sevilla, Spain

${ }^{c}$ Departamento de Química Orgánica, Facultad de Química, Universidad de Sevilla, E41012 Sevilla, Spain

${ }^{d}$ Université de Picardie Jules Verne, Laboratoire de Glycochimie, des Antimicrobiens et des Agroressources, CNRS UMR 7378, 80039 Amiens, France

$\dagger$ Electronic supplementary information (ESI) available. See DOI: 10.1039/c6ra14508f

\$ Present address: Université Pierre et Marie Curie, Institut Parisien de Chimie Moléculaire, CNRS UMR 8232, 4 place Jussieu, 75252 Paris Cedex 05, E-mail: cedric.przybylski@upmc.fr vectors for gene delivery. Nonetheless, concerns exist about their immunogenicity and scaled up production. Indeed some of them have been revealed as insecure in advanced clinical trial stages. ${ }^{1-3}$ Consequently to this bottleneck, alternative ways were explored taking into account the poor stability of DNA in vivo, to design appropriate vectors aiming both to protect the genetic payload from degradation during transport and to enhance cell permeability. ${ }^{4}$ Most of the developed strategies are based on tailoring polycationic agents which self-assemble in the presence of polyanionic nucleic acids to form small (nano-) particles. Polycations have garnered tremendous interest as designed carriers due to their low host immunogenicity and ease of preparation, for example, built from cationic lipid, ${ }^{5-8}$ or also presenting higher molecular weight. ${ }^{8}$ Unfortunately, highmolecular weight polycations usually exhibit high transfection efficiency, but possess high cytotoxicity (e.g. polyethyleneimine, PEI). Consequently, efforts have been made to obtain biocompatible architectures, which can potentially serve as carriers. Some cationic synthetic polymers used as vectors have emerged as a promising alternative because of their scalable production, as well as synthetic ease of tuning their size, structure, and functionality., ${ }^{3,9}$ A number of amine-containing synthetic polymers have been explored to form a polyplex, including for 
example, the paradigmatic PEI, ${ }^{10,11}$ poly-L-lysine (PLL) ${ }^{12}$ poly(2(dimethylamino)ethyl methacrylate) (PDMAEMA) ${ }^{13}$ or also polyamidoamine (PAMAM) dendrimers. ${ }^{14}$ Natural polysaccharides can also be used as a scaffold like chitosan, alginate, dextran, pullulan, cellulose derivatives, cycloamylose, or also hyaluronic acid which are particularly appealing in such case because they are sustainable, non-toxic, and biodegradable. ${ }^{15-20}$ Unfortunately, polycationic based (bio)polymers are quite polydispersed. $^{21}$

Alternatively, molecularly well-defined entities based on macrocyclic scaffolds, ${ }^{22}$ such as calixarenes, ${ }^{23,24}$ pillarenes, ${ }^{25}$ or cyclodextrins (CDs), ${ }^{26,27}$ offer unprecedented opportunities. In this regard, CDs which are cyclic carbohydrates, composed of 6 $(\alpha), 7(\beta)$ and $8(\gamma) \alpha-(1 \rightarrow 4)$ D-glucopyranoside units present several advantages as a well defined structure, high purity, commercial availability as well as low cytotoxicity, and hence are good candidates to serve as a multivalent core for gene delivery agent synthesis. CDs have been elegantly exploited as a molecular scaffold for the design of gene carriers to enhance the gene delivery capabilities of first generation lipidic or polymeric nonviral vectors. ${ }^{7,28,29}$ Such versatility of the molecules with synthetic methodologies permits installing a large array of regioselective functional elements grafted on the CD structure as monodisperse polycationic CDs with ${ }^{28,30-37}$ or without amphiphilic features. ${ }^{34,35,38-41}$

Nevertheless, even considering a well-defined starting scaffold, the synthesis of more complex structures must be controlled with adequate characterization methods. Due to both the nature and number of grafted functions, this remains a challenging task. Since the last two decades, the gentle ionization process electrospray coupled to mass spectrometry (ESIMS) has rapidly gained attraction as a suitable technique to probe sample content. ESI-MS exhibits high sensitivity involving both low sample consumption and residue detection, as compared to other usual methods such as NMR. Moreover, $\mathrm{MS}^{2}$ and beyond allows for performing structural deciphering via sequential fragmentation, making ESI-MS ${ }^{n}$ a major tool for agent characterization. Various carbohydrate species have been largely studied by MS/MS employing various dissociation modes mostly in the low energy regime like collision induced dissociation (CID), which is the most used fragmentation mode for carbohydrates, ${ }^{42}$ and infrared multiphoton dissociation (IRMPD) ${ }^{43}$ Structural deciphering can also be achieved by electron assisted methods such as electron capture dissociation $(\mathrm{ECD}){ }^{44}$ electron transfer dissociation (ETD), ${ }^{45}$ electron detachment dissociation (EDD) ${ }^{46}$ or also ultraviolet photodissociation (UVPD). ${ }^{47}$ Recently, the usefulness of Higher Collision Dissociation (HCD) during ESI-MS ${ }^{2}$ experiments was described for the first time for linear and cyclic carbohydrate characterization, exhibiting complementary information to the usual CID. ${ }^{48,49}$ Nevertheless, to our knowledge, no study has reported the use of ESI-MS and ESI-MS/MS analysis for polycationic carbohydrates whatever the dissociation mode.

In the study herein, we investigated five variously synthesized polycationic cyclodextrin based preparations having demonstrated variable ability to form complexes with RNA/DNA and inducing its compaction. ${ }^{34,35}$ We are committed to confirm the homogeneity of samples, probe and compare their gas phase stability in both CID and HCD mode as a function of charge states as well as to achieve the most accurate sequencing. The goal is to establish the benefits and limitations of such a pairwise combination to serve as a suitable tool to correlate structural determinants to the biological activity relationship.

\section{Experimental section}

\subsection{Chemicals and reagents}

Methanol (MeOH) used for sample preparation was of HPLC grade and was purchased from VWR (West Chester, PA, USA). Ultrapure water was of ultrapure quality, obtained from a MilliQ apparatus (Millipore, Milford, USA).

\subsection{Samples}

Synthesis of per-6-modified- $\beta$-CD. Per-6-amino- $\beta$-CD (agent 1 ), per-6-cysteaminyl- $\beta-\mathrm{CD}$ (agent 2 ), per-6-thioureidocysteaminyl$\beta$-CD (agent 3), per-6-aminoethylthioureidocysteaminyl- $\beta$-CD (agent 4) and per-6-dithioureidocysteaminyl- $\beta$-CD (agent 5) (Fig. 1) were realized as previously described..$^{34,50}$ Samples were prepared at $1 \mathrm{mg} \mathrm{mL}^{-1}$ in water/methanol 1/1 (v/v).

\subsection{Mass spectrometry}

ESI-MS experiments were carried out using a LTQ-Orbitrap XL from Thermo Scientific (San Jose, CA, USA) and operated in positive ionization mode, with a spray voltage at $3.7 \mathrm{kV}$. A water/ methanol $1 / 1(\mathrm{v} / \mathrm{v})$ mixture was continuously infused using a 500 $\mu \mathrm{L}$ syringe at $3 \mu \mathrm{L} \mathrm{min}{ }^{-1}$ flow. Applied voltages were 31 and 115 $\mathrm{V}$ for the ion transfer capillary and the tube lens, respectively. The ion transfer capillary was held at $275^{\circ} \mathrm{C}$. Resolution was set to 60000 (at $\mathrm{m} / \mathrm{z} 400$ ) for all studies, and the $\mathrm{m} / \mathrm{z}$ ranges were set to 200-2000 in profile mode and in the normal mass range during full scan experiments. Spectra were analyzed using the acquisition software XCalibur 2.0.7 (Thermo Scientific, San Jose, CA, USA) without smoothing and background subtraction. During MS/MS scans, collision-induced dissociation (CID) was performed with an activation $Q$ value of 0.25 and an activation time of $30 \mathrm{~ms}$, which occurred in the linear ion trap analyzer (LTQ) and detection in the Orbitrap in centroid mode. This mode used helium as gas (at a pressure of 2 bar) by adjusting the resonance excitation AC signal of $0-5 \mathrm{~V}$ (zero-to-peak) at the secular frequency of the precursor ion $m / z$ value. Higher energy collision dissociation (HCD) experiments were performed with an activation time of $100 \mathrm{~ms}$, according to our previous study for oligosaccharides ${ }^{49}$ and occurred in an octopole collision cell aligned to the C-trap and detection in the Orbitrap. This dedicated cell is supplied with an rf voltage $\left(2.6 \mathrm{MHz}, 500 \mathrm{~V}_{\mathrm{p}-\mathrm{p}}\right)$ of which the DC offset can be varied by $\pm 250 \mathrm{~V}$ and crossed with nitrogen gas at a pressure of $5 \times 10^{-3}$ mbar. For all modes, the endcap voltage was controlled by the normalized collision energy (NCE) technology, where collision energy was modified for each experiment and is expressed in \% of NCE. The peak-topeak voltage is scaled as $V_{\mathrm{p}-\mathrm{p}}=\mathrm{NCE} / 30 \times(a(m / z)+b)$, where $a$ and $b$ are instrument variable parameters set at 0.002 and 0.4 , 

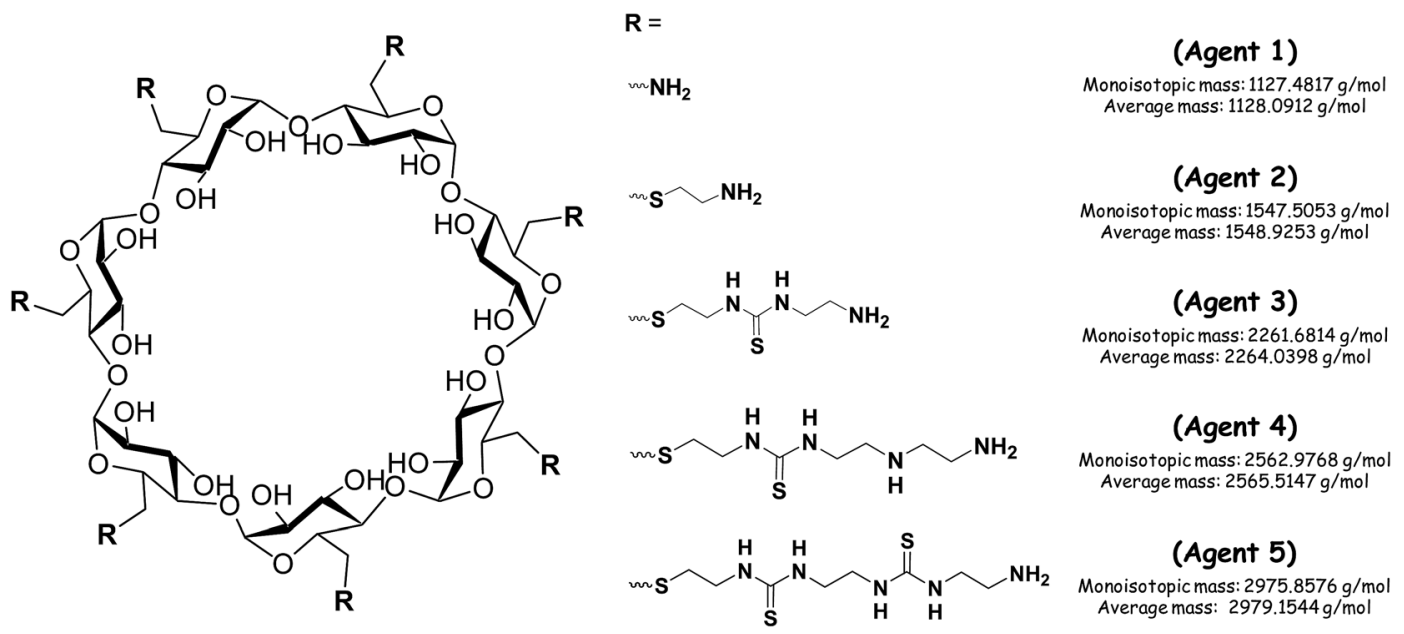

Fig. 1 Structures of the five polycationic carbohydrate based non-viral gene delivery agents (agent 1 to 5) studied herein.

respectively. The standard range is $0 \%$ to $100 \%$ corresponding to $0-5 / 500 \mathrm{~V}$ according to the dissociation mode. During the survival yield experiments, the NCE varied from 0 to $70 \%$, while for other experiments in the CID and HCD modes, the NCE was set to the estimated $\mathrm{CE}_{50}$ value (Table 1) and the precursor selection window was set to 2.8 Da during $\mathrm{MS}^{2}$ experiments in both dissociation modes. The automatic gain control (AGC) allowed accumulation of up to $10^{6}$ ions for FTMS scans, $2 \times 10^{5}$ ions for FTMSn scans and $3 \times 10^{4}$ ions for ITMSn scans. Maximum injection time was set to $500 \mathrm{~ms}$ for both FTMS and FTMSn scans and $100 \mathrm{~ms}$ for ITMSn scans. For all scan modes, 1 $\mu$ scan was acquired. Fragments resulting from fragmentation steps were annotated according to the nomenclature described by Domon and Costello, ${ }^{51}$ and adapted for cyclodextrins. ${ }^{48}$

\section{Results and discussion}

\subsection{Full MS spectra}

Obtaining a simple MS spectrum can, in some case, represent a challenging task, especially for polycationic and polyanionic compounds, while it constitutes the first and the easier step to gain a portrait of the sample content. Neutral carbohydrates are polyol compounds well known to easily form adducts with metal cations $\left(\mathrm{Na}^{+}, \mathrm{K}^{+}, \mathrm{Li}^{+}, \ldots\right)$ or ammonium ion $\left(\mathrm{NH}_{4}^{+}\right) .^{52-54}$ Notwithstanding, in the study herein the carbohydrates have been chemically modified and present a strong cationic character involving a clear preference for protons. Moreover, the maximal possible charge states depend on several protonable sites, i.e. the number of primary and secondary amines $\left(\mathrm{NH}_{2}\right.$ and $\mathrm{NH}$, respectively) but also sulfur (S). For agents 1, 2, 3, 4 and 5 , this theoretical number is $7\left(\mathrm{NH}_{2}: 7\right), 14\left(\mathrm{NH}_{2}: 7, \mathrm{~S}: 7\right), 35$ $\left(\mathrm{NH}_{2}: 7, \mathrm{NH}: 14, \mathrm{~S}: 14\right), 42\left(\mathrm{NH}_{2}: 7, \mathrm{NH}: 21, \mathrm{~S}: 14\right)$ and $56\left(\mathrm{NH}_{2}: 7\right.$, NH: 28, S: 21), respectively. Nevertheless, it can be anticipated that all these groups cannot simultaneously attach protons, mainly due to coulombic repulsion, involving a dedicated rigidity conformation of molecules, steric hindrance and a particular hydration shell. Full MS spectra reveal that agent charge states were between 1+ and 7+ (Fig. 2).
A majority of reports suggest that the maximum charge carried by amino based biomolecules such as denaturated protein until $\approx 50 \mathrm{kDa}$, can be directly correlated to their number of basic residues (Arg, Lys and His). ${ }^{55}$ However, a previous study especially on higher molecular weight proteins and polyamidoamine based stardust dendrimers gave evidence that features such as solvent, ${ }^{56}$ and above all, coulombic repulsion effects directly affect the effective maximum and average charging. ${ }^{57-59}$ For high molecular weight proteins, the maximum number of charges $\left(Z_{\max }\right)$ observed is smaller and is thought to be obtained by combining the accessibility of basic amino acid side chains near the surface of ESI droplets, and the size and surface tension of the droplets as described by the Rayleigh limit $\left(Z_{\mathrm{R}}\right)^{59-61}$ Considering a spherical ion in the gas phase, the charge state distribution was dependent on the coulombic repulsion required to lower the energy barrier of proton transfer. From this, Schwartz et al. argued that, since the volume (and hence the resulting mass) varies as $r^{3}$ (with $r$ the radius of the ion) the number of charges on the ion varies as (molecular weight $)^{2 / 3}$. This study has demonstrated than even if protein sequence is heterogeneous as compared to studied dendrimers, the globular shape of both involves a similar gasphase behaviour and then an identical extent of charging. ${ }^{57}$ Another study based on the Dole's charged residue mechanism demonstrated that the maximum theoretical charge is $Z_{\max }$ theo $=Z_{\mathrm{R}}=0.0778 \times\left(\text { average molecular mass; } M_{\mathrm{w}}\right)^{1 / 2}$ for native globular proteins and compact starburst dendrimer ions..$^{58,59}$ Some other ions representing a more extended structure such as linear chains of polyethylene glycols have experimental $Z_{\max }$ $\left(Z_{\max } \exp \right)$ values considerably larger than $Z_{\mathrm{R}}\left(Z_{\max } \exp / Z_{\mathrm{R}}>1\right)$ which could also be formed from the charged residue mechanism, but with non-spherical drops held together by the polymer backbone. ${ }^{59}$

Taking into account the aforementioned equation ${ }^{58,59}$ and the experimental spectra, we obtain the following $Z_{\max } \exp / Z_{\mathrm{R}}$ ratio values: 1.14 (3/2.61), 1.31 (4/3.06), 1.89 (7/3.70), 1.77 (7/ $3.94)$ and $1.65(7 / 4.24)$ for agent $1,2,3,4$ and 5, respectively. It is noteworthy that the relative stability of highly-charged 
Table 1 Recapitulative table of mass accuracy and characteristic CE$_{50}$ values obtained in CID and HCD modes for different studied agents according to their respective charge states $^{a}$

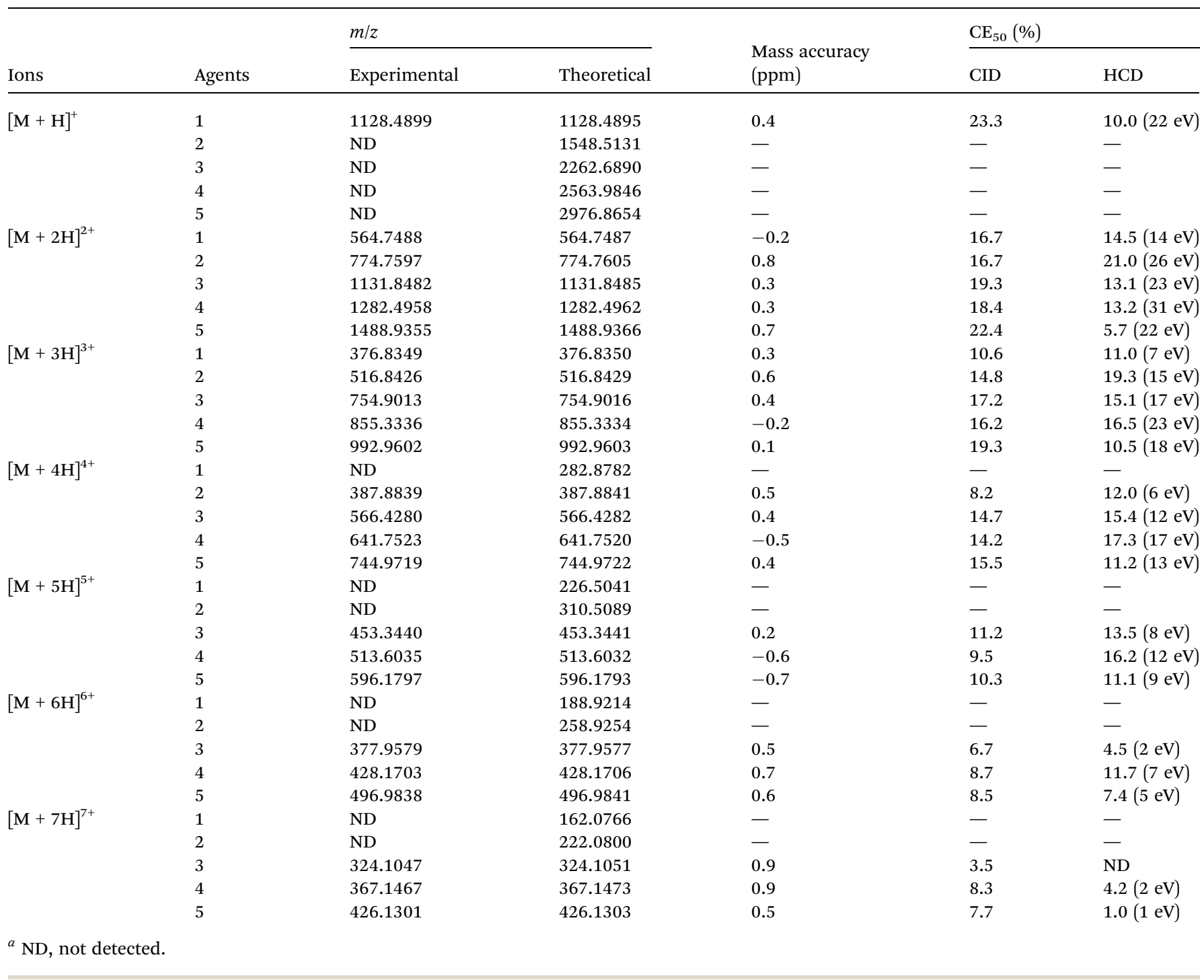

species conferred by the 2-aminoethyl-thioureido segment (present in CDs 3, 4 and 5) nicely correlates with the enhanced gene transfer capabilities of amphiphilic CDs containing this functional group (see for instance ${ }^{34}$ ). The two last ones exhibit more complex spectra than for others presumably due to more reactive moieties inducing rearrangement and additional loss in the gas phase. However, thanks to both the high resolution power and mass accuracy of the Orbitrap analyzer, this did not impair the correct ascription of ions and their accurate selection for fragmentation. The first step is to determine the different stability level in the gas phase of molecules as a function of their respective different charge states.

\subsection{Probing gas phase stability}

A measure of the propensity of a structure to dissociate was obtained by determining the collision energy required to obtain $50 \%$ of the precursor decomposition ( $\mathrm{CE}_{50}$ value). Here, these values can serve as a tool to probe the strength i.e. the stability of the protonated structures in the gas phase. Such a benchmark was established for every detected charge state i.e. here the number of attached protons. This criterion was previously successfully applied to compare carbohydrate features such as for example the length, ${ }^{\mathbf{4 9}, 62}$ the cyclic or linear forms, ${ }^{49}$ the degree of methylation/number and kind of cations attached. ${ }^{48} \mathrm{It}$ is well known that Collision Induced Dissociation (CID) is the widely used fragmentation mode to establish the survival yield curves of several molecules. This CID mode operates as a "slow" regime with 1-20 eV at the low ms scale and with approximately 10-1000 collisions per s. Nevertheless, we have previously demonstrated that High Collision Dissociation (HCD), available on a LTQ-Orbitrap instrument, provides an alternative way of fragmentation. Indeed, HCD uses a "triple quadrupole like" fragmentation mechanism which offers fine tuning to monitor agent decomposition such as oligomaltosides and native or 
A

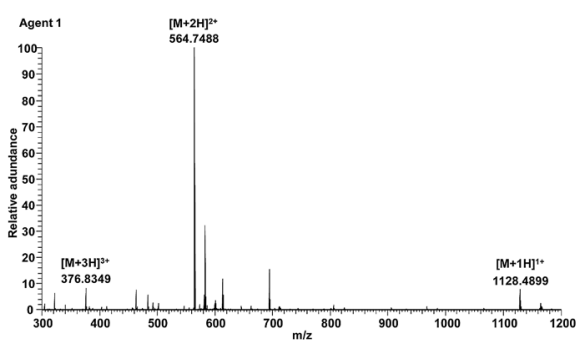

B

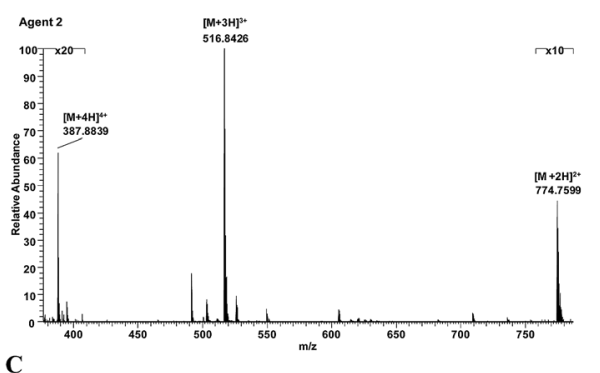

C

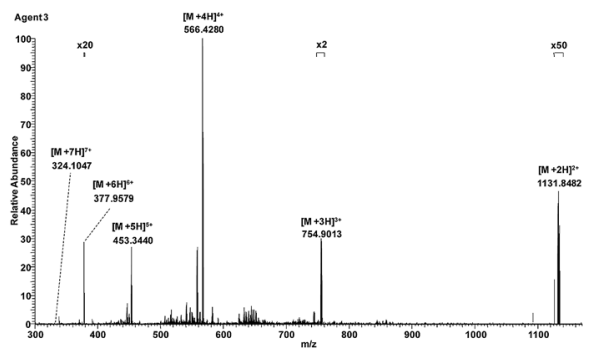

D

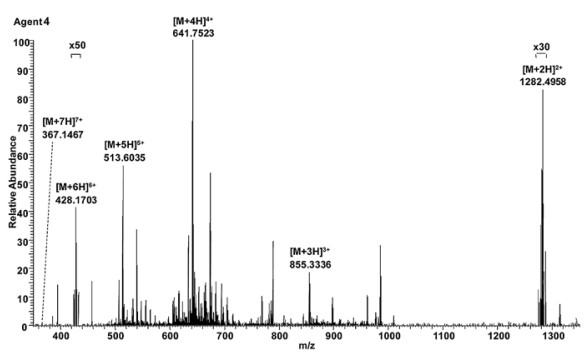

$\mathbf{E}$

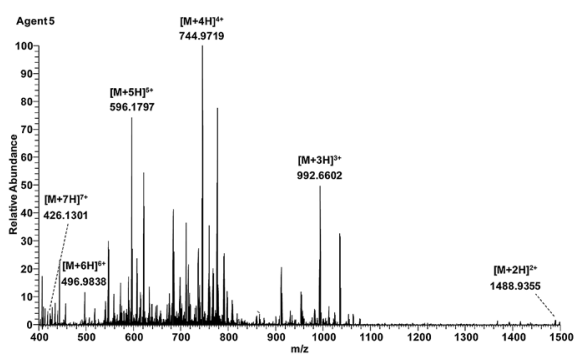

Fig. 2 Full mass spectra of agent 1 (A) 1, 2 (B), 3 (C), 4 (D) and 5 (E).

methylated CDs. ${ }^{\mathbf{4 8 , 4 9}}$ HCD mode operates as a "fast" CID mode with 1-200 eV at a high ms scale at an average lower collision rate with approximately 10-100 collisions per $\mathrm{s}$. The determination of $\mathrm{CE}_{50}$ values was achieved both in CID and HCD dissociation modes. Here, such values can serve as a tool to observe differences in fragmentation susceptibility between various molecules according to a given charge state as well as to study behaviour of a given molecule under different protonation levels i.e. establish a $\mathrm{CE}_{50} /$ charge states relationship. The NCE was increased by increments of $0.5 \%$ from $0 \%$ to $70 \%$. After NCE screening, the intensity of the precursor ion was recorded as a function of the NCE. The SY was calculated following the equation $S Y=\left(I_{\mathrm{X}}\right) /\left(I_{0}\right)$, where $I_{\mathrm{X}}$ is the intensity of the precursor ion peak after excitation with a specific percentage of NCE, and $I_{0}$ is the intensity of the precursor ion peak after excitation with 0\% NCE. Experimental points were next fitted to plot a sigmoid curve, from which $\mathrm{CE}_{50}$ values were deduced as in previous studies. ${ }^{48,49}$ The determination of $\mathrm{CE}_{50}$ values during both CID and HCD dissociation experiments was achieved for the $[\mathrm{M}+n \mathrm{H}]^{n+}$ with $1 \leq n \leq 7$ for each of the five studied cationic carbohydrates (Table 1 ).

Thorough examination of the results in Table 1 reveals some interesting differences such as the fact that di- and triply charged ions of agent 1 required almost two fold less HCD energy than other agents. Concerning quadruply charged, agent 2 required 2-3 fold CID or HCD less energy than others, while all values are quite close for $5+$. Considering the HCD mode, sextuply charged ions exhibit similar trends compared to quadruply charged ones from agent 4 and 5 . The case of sextuply charged ions can be set apart, since only three agents show such charge states with agent 3 being $\approx 2.3$ fold more sensitive to CID fragmentation than others. Moreover, this agent presented too low abundance to be effectively studied by HCD, while agents 4 and 5 exhibited a highly unstable behaviour, leading rapidly to dissociation. In both HCD and CID mode, a quite poor correlation was observed (main regression coefficient $R^{2}$ between $0.2032-0.8659$ and $0.00231-0.6807$ for CID and HCD, respectively, considering at least three points) between the $\mathrm{CE}_{50}$ values and the $\mathrm{m} / \mathrm{z}$ for all carbohydrate derivatives (ESI Fig. S1†). That contrasts with previous results obtained with polymers, ${ }^{62,63}$ oligo-/polysaccharides ${ }^{48,49,62}$ or peptides. ${ }^{64}$ In this last case, it was observed that dispersion of the experimental points was higher for triply charged than singly or doubly charged ions. This can be attributed to more mobile protons and consequently to various peptides gas phase conformations. ${ }^{64}$ From the data, the behaviour of each agent towards both their charge states and dissociation mode used is quite contrasted. Nonetheless, two trends can be drawn: (i) the progressive increase of charge states involved moderate and constant reduction dissociation energy $(\approx 2-4 \%$ and $\approx 7-10 \mathrm{eV}$ in CID and HCD, respectively, except for agent 1 where a loss of $\approx 6 \%$ and $7-8 \mathrm{eV}$ is obtained in CID and HCD, respectively), (ii) based on $\mathrm{CE}_{50}$ values, agent 4 or 5 appeared as the most stable according to the investigated charge state ranges and according to the dissociation mode like CID and HCD, respectively. Such phenomenon could be attributed to charge delocalization on the 2-aminoethyl-thiourea segments. On the other hand, a clear linear correlation was obtained after fitting the $\mathrm{CE}_{50}$ value obtained upon HCD with charge states as evidenced by the regression coefficient all between 0.9958 and 0.9987 (Fig. 3). 
Here, such results revealed a higher influence value of the number of protons attached on the $\mathrm{CE}_{50}$ rather than considering only the $\mathrm{m} / \mathrm{z}$ ratio. Based on the mobile proton theory, well known for peptides and proteins, the higher the number of proton acceptor sites, the higher the probability to induce cleavage. Indeed, due to this strong effective correlation, we can postulate that protons are statistically distributed along molecules in regards to their proton affinity (PA) sites. Among them, we delineate methylamine $\left(\mathrm{CH}_{3} \mathrm{NH}_{2}, \mathrm{PA}: 899.0 \mathrm{~kJ} \mathrm{~mol}^{-1}\right)$ for agent 1, ethylamine $\left(\mathrm{CH}_{3} \mathrm{CH}_{2} \mathrm{NH}_{2}\right.$, PA: $\left.912.0 \mathrm{~kJ} \mathrm{~mol}^{-1}\right)$ for agents 2 to 5 , one dimethylamine $\left(\left(\mathrm{CH}_{3}\right)_{2} \mathrm{NH}_{2}, \mathrm{PA}: 929.5 \mathrm{~kJ}\right.$ $\mathrm{mol}^{-1}$ ) for agent 4 and one or two $N, N$-di-methylthiourea moieties $\left(\left(\mathrm{CH}_{3} \mathrm{NH}\right)_{2} \mathrm{CS}\right.$, PA: $\left.926.0 \mathrm{~kJ} \mathrm{~mol}^{-1}\right)$ in agent 3 and $4 / 5$, respectively. An additional moiety can be also taken into account, thioruea $\left(\left(\mathrm{CH}_{3} \mathrm{NH}\right)_{2} \mathrm{CS}, \mathrm{PA}: 897.3 \mathrm{~kJ} \mathrm{~mol}^{-1}\right)$ but it did not match very well with our structures, since it requires $N, N$ free amino groups. Careful examination of the data in Fig. 3 showed that molecules present different behaviour according to the range of available charge states. In this sense, the slope and intercept of the curve could be used as tools to tentatively discriminate structures. Hence, according to the aforementioned criteria, especially slope, studied molecules can be divided into three sets. The first contains agents 1 and 2 with a higher slope of $-7.5 \mathrm{eV}$ per CS and $-10 \mathrm{eV}$ per CS, respectively, showing that they are highly prone to fragment consequent to the increase in charge states. The second set includes agents 3 and 5 which demonstrated a quite similar behaviour with a slope as well of -5.1 and $-5.4 \mathrm{eV}$ per CS, respectively, revealing the lowest influence of charge states upon fragmentation susceptibility ( $\approx 2-3$ lower than for agents $1 / 2$ ). Finally, a third set was only composed of agent 4 exhibiting an intermediary regime with a slope equal to $-4.2 \mathrm{eV}$ per CS.

At a glance, the intercept values did not really make sense from a physico-chemical point of view, appearing only as $\mathrm{CE}_{50}$ values when a 0 net charge is borne i.e. a neutral molecule. Only between agents 1 and 2 were values almost one-third higher (45.7 versus $29.3 \mathrm{eV}$, all other agents values are between 30.4 and $39.2 \mathrm{eV}$ ). That means that, intrinsically, $\mathrm{CE}_{50}$ values without any charges are close, demonstrating the influence of the number of charges on the fragmentation propensity as compared to only the initial molecular conformation. Nonetheless, these values

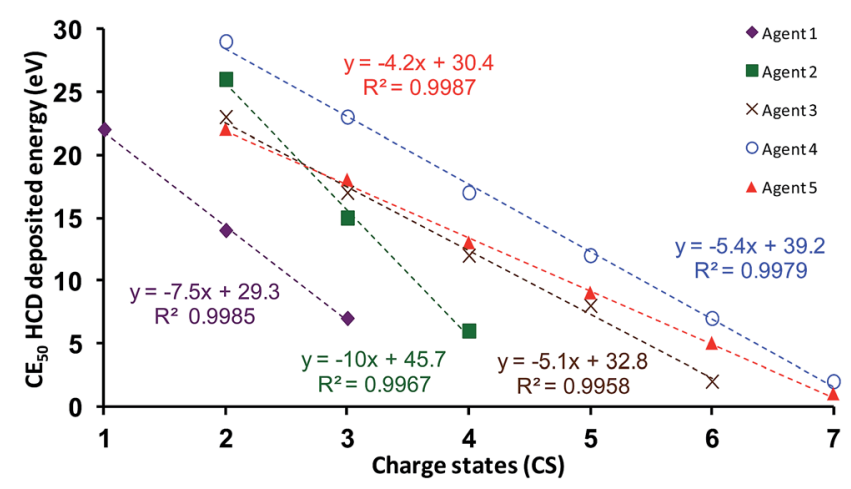

Fig. 3 Variation of $\mathrm{CE}_{50}$ HCD values as a function of charge states from the five studied agents. could be used to determine experimental appearance energies $\left(\mathrm{AE}_{\exp }\right)$, i.e. the minimum energy that must be imparted to the molecule to produce an ion, determined in the NCE framework of a given IT-MS as previously demonstrated by Zins et al. ${ }^{65}$ That required the application of a single conversion factor from the linear fit of $9.8 \pm 0.3 \mathrm{~kJ} \mathrm{~mol}^{-1} \%^{-1}$ between the $\%$ NCE scale and $\mathrm{kJ} \mathrm{mol}^{-1}$ (i.e. $\mathrm{AE}_{\text {exp }}=9.8 \times \% \mathrm{NCE}$ ). After conversion, we can postulate that the presence of only an amino group (agent 1, $\mathrm{AE}_{\text {exp }}: 287 \mathrm{~kJ} \mathrm{~mol}^{-1}$ ) offers better conditions to rapidly promote efficient ionisation. Next, dithioureidocystenaminyl (agent 5, $\mathrm{AE}_{\text {exp }}: 298 \mathrm{~kJ} \mathrm{~mol}^{-1}$ ) or an exhibiting thioureidocystenaminyl arm (agent 3, $\mathrm{AE}_{\text {exp }}: 321 \mathrm{~kJ} \mathrm{~mol}^{-1}$ ) is a little less easy to ionize. This could be due to a more compact structure consequent to the intra-molecular hydrogen bond emphasized due to the two thioureido moieties for agent 5, and lower PA of the single primary amine for agent 1 . The presence of aminoethylthioureidocystenaminyl (agent 4, AE $\mathrm{exp}_{\mathrm{e}}$ : $384 \mathrm{~kJ} \mathrm{~mol}^{-1}$ ) exhibits only one thiourea moiety, as agent 3 , but the presence of a ternary amine could involve higher flexibility providing a particular conformation of the grafted chains. Finally, the cysteaminylated molecules (agent 2, AE $\mathrm{Exp}_{\exp } 448 \mathrm{~kJ} \mathrm{~mol}^{-1}$ ) appeared as the most difficult to ionize. However, our experimental AE values must be treated with particular caution, since those previously reported were determined according to the monocharged ion, and not as a extrapolated neutral molecular state. Taking into account both the most abundant charge states as a function of targeted agents (full MS spectra) and determining the relative gas phase stability of each structure according to their protonation state $\left(\mathrm{CE}_{50}\right.$ value), better characterization is required by the sequencing of modification/ grafted arms.

\subsection{Structural deciphering via combined CID and HCD fragmentation experiments}

Here, even if all detected charges corresponding to intact agents have been fragmented, we only reported the fragmentation spectra of the most intense precursor for each agent according to their respective charge state. If CID is a standard fragmentation technique easily accessible in present-day instruments, it suffers from the low-mass cutoff bottleneck which does not allow the trapping of fragments below $\approx 30 \%$ of the precursor $\mathrm{m} / \mathrm{z}$. This one-third rule is governed by the choice of the instrumental $Q$ value depending on the rf amplitude. An alternative way is the recently introduced HCD fragmentation in a not $Q$ dependent matter. With the CID and HCD fragmentation mode, common losses of $\mathrm{NH}_{3}(-17.027$ mass units, $\square$ at the precursor charge state and $\boldsymbol{\square}$ for lower charge states) and $\mathrm{H}_{2} \mathrm{O}(-18.011$ mass units, $\diamond$ at the precursor charge state and $\checkmark$ for lower charge states) were observed. The fragmentation of dicharged ions of per-6-amino-CD (agent 1) mainly yielded to $\mathrm{NH}_{3}$ and $\mathrm{H}_{2} \mathrm{O}$ losses (Fig. 4A). Nonetheless, enough energy was dissipated to also allow some glycosidic cleavage along the oligosaccharide backbone, but more efficiently by producing monocharged ions rather than dicharged ones. Indeed, only $\mathrm{m} / \mathrm{z}$ 484.2155 corresponding to $\left[\mathrm{C}_{7} / \mathrm{Z}_{6}+2 \mathrm{H}\right]^{2+}$ ion was clearly detected while $\mathrm{m} / \mathrm{z}$ 967.4212, $\mathrm{m} / \mathrm{z}$ 806.3522, $\mathrm{m} / \mathrm{z}$ 645.2828, 
484.2155, $\mathrm{m} / \mathrm{z} 323.1457$ and $\mathrm{m} / \mathrm{z} 162.0764$ were ascribed to $\left[\mathrm{C}_{7} /\right.$ $\left.\mathrm{Z}_{n}+\mathrm{H}\right]^{+}$with $1<n<6$, respectively. Three additional ion series were also observed, the first two were attributed to the glycosidic cleavage at $m / z 341.1566\left(\left[\mathrm{C}_{7} / \mathrm{Y}_{2}+\mathrm{H}\right]^{+}\right)$and $m / z 180.0871\left(\left[\mathrm{C}_{7} /\right.\right.$ $\left.\left.\mathrm{Y}_{1}+\mathrm{H}\right]^{+}\right)$i.e. $\left[\mathrm{GlcNH}_{2}+\mathrm{H}\right]^{+}$or with $\mathrm{Y}$ series at $m / z 323.14576\left(\left[\mathrm{C}_{7} /\right.\right.$ $\left.\left.\mathrm{Z}_{2}+\mathrm{H}\right]^{+}\right)$and $m / z 162.0764\left(\left[\mathrm{C}_{7} / \mathrm{Z}_{1}+\mathrm{H}\right]^{+}\right)$i.e. $\left(\left[\mathrm{GlcNH}_{2}-\mathrm{H}_{2} \mathrm{O}+\right.\right.$ $\mathrm{H}]^{+}$), and the third one including the loss of one $\mathrm{CHNH}_{2}$ moiety at $m / z 884.3626\left(\left[\mathrm{C}_{7} / \mathrm{Z}_{6}-3 \mathrm{H}_{2} \mathrm{O}-\mathrm{CHNH}_{2}+\mathrm{H}\right]^{+}\right)$and $m / z$ $532.2237\left(\left[\mathrm{M}-2 \mathrm{H}_{2} \mathrm{O}-\mathrm{CHNH}_{2}+2 \mathrm{H}\right]^{2+}\right)$. In HCD mode, similar ions were detected, but exhibited a more balanced spectrum over the whole spectrum. In particular, higher low mass intensity signals corresponding to one building block, and the presence of additional water loss from $m / z 532.2242\left(\left[\mathrm{M}-2 \mathrm{H}_{2} \mathrm{O}\right.\right.$ $\left.-\mathrm{CHNH}_{2}+2 \mathrm{H}\right]^{2+}$ ) were observed (Fig. $4 \mathrm{~B}, \mathrm{O}$ at the precursor charge state).

Concerning per-6-cysteaminylated CD (agent 2), in CID, both ammonia and water losses were still highly abundant, associated or not with glycosidic cleavages (Fig. 5A). Nevertheless, these fragments were less abundant as triply charged for example at $m / z 431.4728,\left(\left[\mathrm{C}_{7} / \mathrm{Z}_{6}-\mathrm{H}_{2} \mathrm{O}-\mathrm{NH}_{3}+3 \mathrm{H}\right]^{3+}\right)$ than for a simple charge reduction or as doubly charged at $\mathrm{m} / z 664.2121$ $\left(\left[\mathrm{C}_{7} / \mathrm{Z}_{6}+2 \mathrm{H}\right]^{2+}\right), m / z 553.6877\left(\left[\mathrm{C}_{7} / \mathrm{Z}_{5}+2 \mathrm{H}\right]^{2+}\right), m / z 434.6418\left(\left[\mathrm{C}_{7} /\right.\right.$
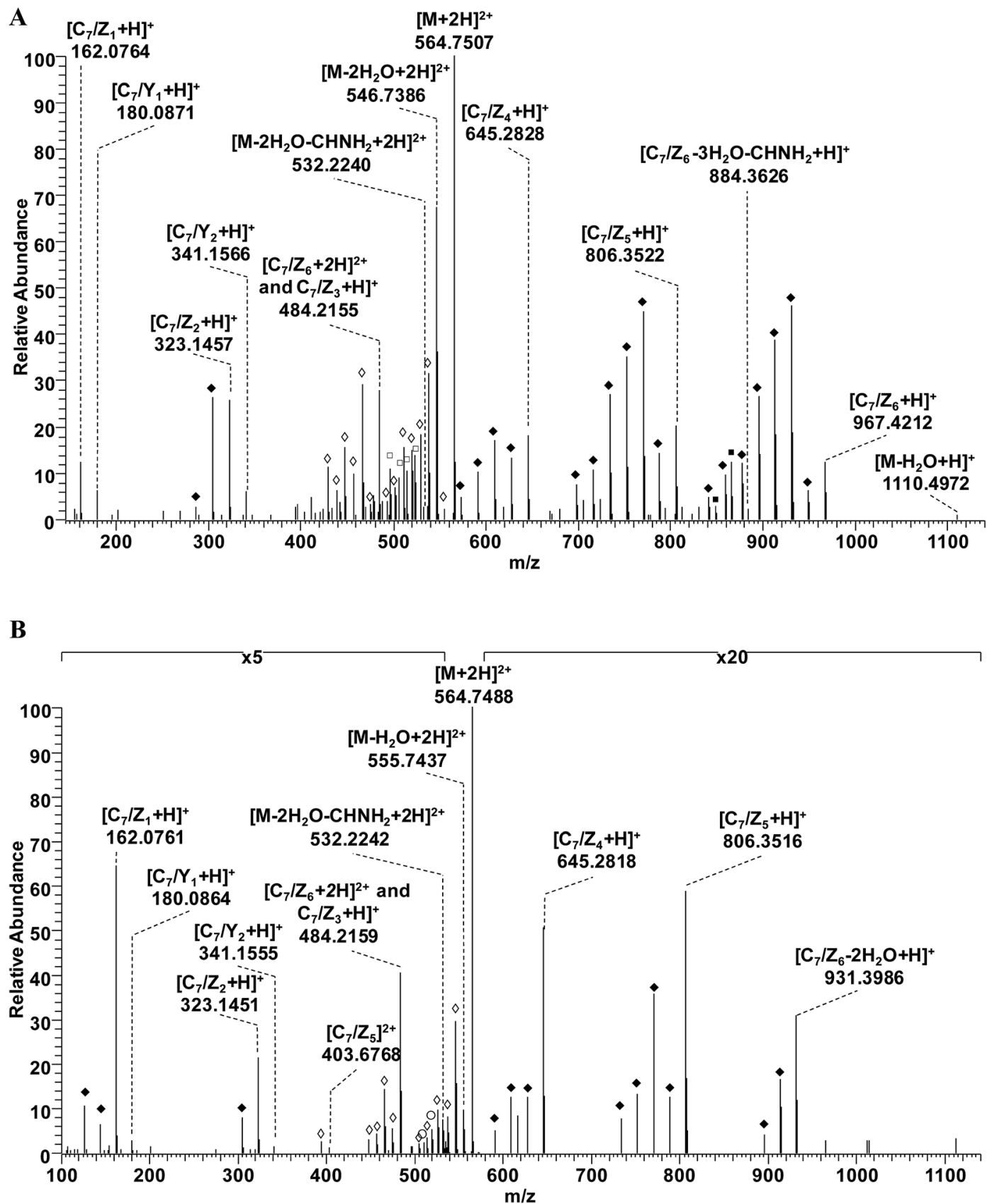

Fig. $4 \mathrm{MS} / \mathrm{MS}$ spectra obtained for fragmentation of $[\mathrm{M}+2 \mathrm{H}]^{2+}$ of agent 1 in $\mathrm{CID}(\mathrm{A})$ and $\mathrm{HCD}(\mathrm{B})$. NH $\mathrm{N}_{3}$ loss at the precursor ( $\square$ ) and lower charge states; $\mathrm{H}_{2} \mathrm{O}$ loss at the precursor $(\diamond)$ and lower $(\diamond)$ charge states; additional $\mathrm{H}_{2} \mathrm{O}$ loss $(\wedge)$ from $\left[\mathrm{M}-2 \mathrm{H}_{2} \mathrm{O}-\mathrm{CHNH}_{2}+2 \mathrm{H}^{2+}\right.$ loss. 
$\left.\left.\mathrm{Z}_{4}-\mathrm{NH}_{3}+2 \mathrm{H}\right]^{2+}\right)$ and $m / z 324.1003\left(\left[\mathrm{C}_{7} / \mathrm{Z}_{3}-\mathrm{NH}_{3}+2 \mathrm{H}\right]^{2+}\right)$ as well as a monocharged one like at $m / z 851.2429\left(\left[\mathrm{C}_{7} / \mathrm{Z}_{4}-2 \mathrm{NH}_{3}+\right.\right.$ $\left.\mathrm{H}]^{+}\right), 649.1913\left(\left[\mathrm{C}_{7} / \mathrm{Z}_{3}-\mathrm{NH}_{3}+\mathrm{H}\right]^{+}\right)$and for $m / z 426.1241\left(\left[\mathrm{C}_{7} / \mathrm{Z}_{2}\right.\right.$ $\left.-\mathrm{NH}_{3}+\mathrm{H}\right]^{+}$). It must be noted that this last ion is the first part of an isotopic cluster (data not shown) including also a dicharged species $\left[\mathrm{C}_{7} / \mathrm{Z}_{4}-2 \mathrm{NH}_{3}+2 \mathrm{H}\right]^{2+}$. The presence of an thioether group on the grafted arms induces site driven fragmentation which can occur at the $\alpha$ position of the two sides of the $\mathrm{S}$ atom, leading to $\left(\mathrm{CH}_{2}\right)_{2} \mathrm{NH}($ e.g. $\mathrm{m} / z \mathbf{z} 74.7255$ for $[\mathrm{M}-$ $\left.\left.\left(\mathrm{CH}_{2}\right)_{2} \mathrm{NH}-\mathrm{NH}_{3}+2 \mathrm{H}\right]^{2+}\right)$ or $\mathrm{SH}\left(\mathrm{CH}_{2}\right)_{2} \mathrm{NH}_{2}$ losses. Nonetheless, in this last case, such loss involves obligatorily the concomitant loss of one water molecule and intra-cyclic cleavage (i.e. $\mathrm{m} / \mathrm{z}$ 697.2292 and $m / z 465.1562$ for $\left[{ }^{0,2} \mathrm{~A}_{7} / \mathrm{Z}_{7}-\mathrm{SH}\left(\mathrm{CH}_{2}\right)_{2} \mathrm{NH}_{2}-\mathrm{H}_{2} \mathrm{O}+\right.$ $2 \mathrm{H}]^{2+}$ and $\left[{ }^{0,2} \mathrm{~A}_{7} / \mathrm{Z}_{7}-\mathrm{SH}\left(\mathrm{CH}_{2}\right)_{2} \mathrm{NH}_{2}-\mathrm{H}_{2} \mathrm{O}+3 \mathrm{H}\right]^{3+}$, respectively). Monocharged monosaccharide with no reducing end exhibiting unsaturation (i.e. coming from sequential rupture of CD's glycosidic bond) and carrying a cysteaminyl moiety was detected as an intact form at $m / z 222.0798\left(\left[\mathrm{C}_{7} / \mathrm{Z}_{1}+\mathrm{H}\right]^{+}\right.$i.e. $\left.\left[\mathrm{GlcS}\left(\mathrm{CH}_{2}\right)_{2} \mathrm{NH}_{2}-\mathrm{H}_{2} \mathrm{O}+\mathrm{H}\right]^{+}\right)$and after deamination at $\mathrm{m} / \mathrm{z}$ $205.0528\left(\left[\mathrm{C}_{7} / \mathrm{Z}_{1}-\mathrm{NH}_{3}+\mathrm{H}\right]^{+}\right.$i.e. $\left[\mathrm{GlcS}\left(\mathrm{CH}_{2}\right)_{2} \mathrm{NH}_{2}-\mathrm{H}_{2} \mathrm{O}-\right.$ $\left.\left.\mathrm{NH}_{3}+\mathrm{H}\right]^{+}\right)$or further dehydration $(\mathrm{m} / z$ 205.0528, $\mathrm{m} / \mathrm{z}$ 186.0581, $\mathrm{m} / \mathrm{z}$ 168.0478, for additional 1,2 and 3 water losses,
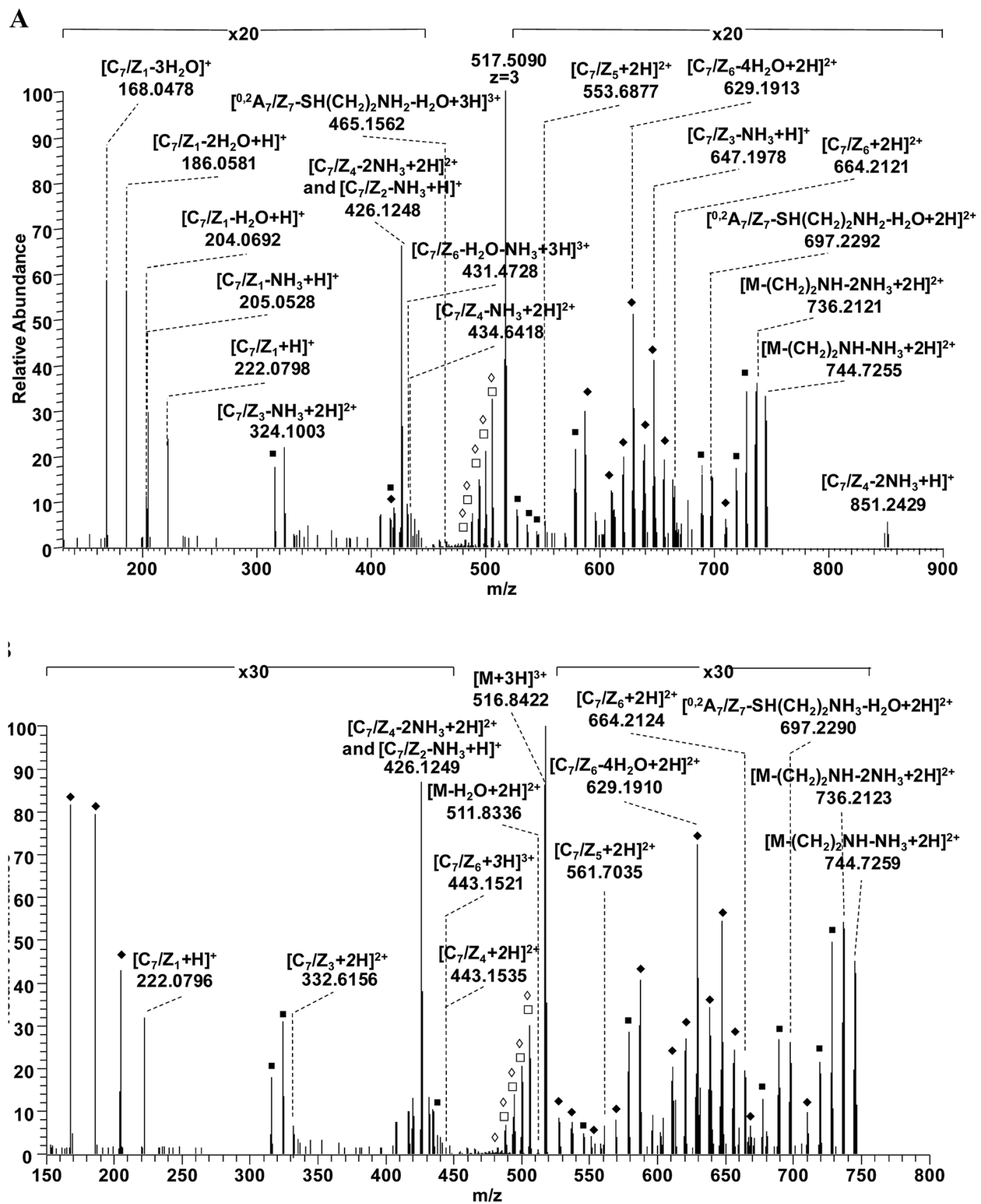

Fig. $5 \mathrm{MS} / \mathrm{MS}$ spectra obtained for fragmentation of $[\mathrm{M}+3 \mathrm{H}]^{3+}$ of agent 2 in $\mathrm{CID}(\mathrm{A})$ and $\mathrm{HCD}(\mathrm{B})$. NH $\mathrm{N}_{3}$ loss at the precursor ( $\square$ ) and lower ( charge states; $\mathrm{H}_{2} \mathrm{O}$ loss at the precursor $(\diamond)$ and lower $(\diamond)$ charge states. 
respectively). Here, the precursor under $3+$ upon HCD fragmentation did not significantly improve the sequence covering of the cyclic carbohydrate and did not produce neither more nor different fragments as compared to CID (Fig. 5B).

The CID based MS/MS spectrum of the quadruply charged ion from agent 3 (Fig. 6A) showed few similar ions as that of agent 2, with only the loss of $\left(\mathrm{CH}_{2}\right)_{2} \mathrm{NH}($ e.g. $\mathrm{m} / z 734.8793$ and for $m / z 551.4116$ for $\left[\mathrm{M}-\left(\mathrm{CH}_{2}\right)_{2} \mathrm{NH}-\mathrm{NH}_{3}+3 \mathrm{H}\right]^{3+}$ and for $[\mathrm{M}-$ $\left.\left(\mathrm{CH}_{2}\right)_{2} \mathrm{NH}-\mathrm{NH}_{3}+4 \mathrm{H}\right]^{4+}$, respectively). Otherwise, the presence of the thioureidocystenaminyl moiety induces some particular site driven fragmentation corresponding to the loss of $\mathrm{CS}\left(\mathrm{CH}_{2}\right)_{2}(\mathrm{NH})_{2}($ e.g. $m / z 700.8713$ and for $m / z 540.9213$ for $[\mathrm{M}-$

A
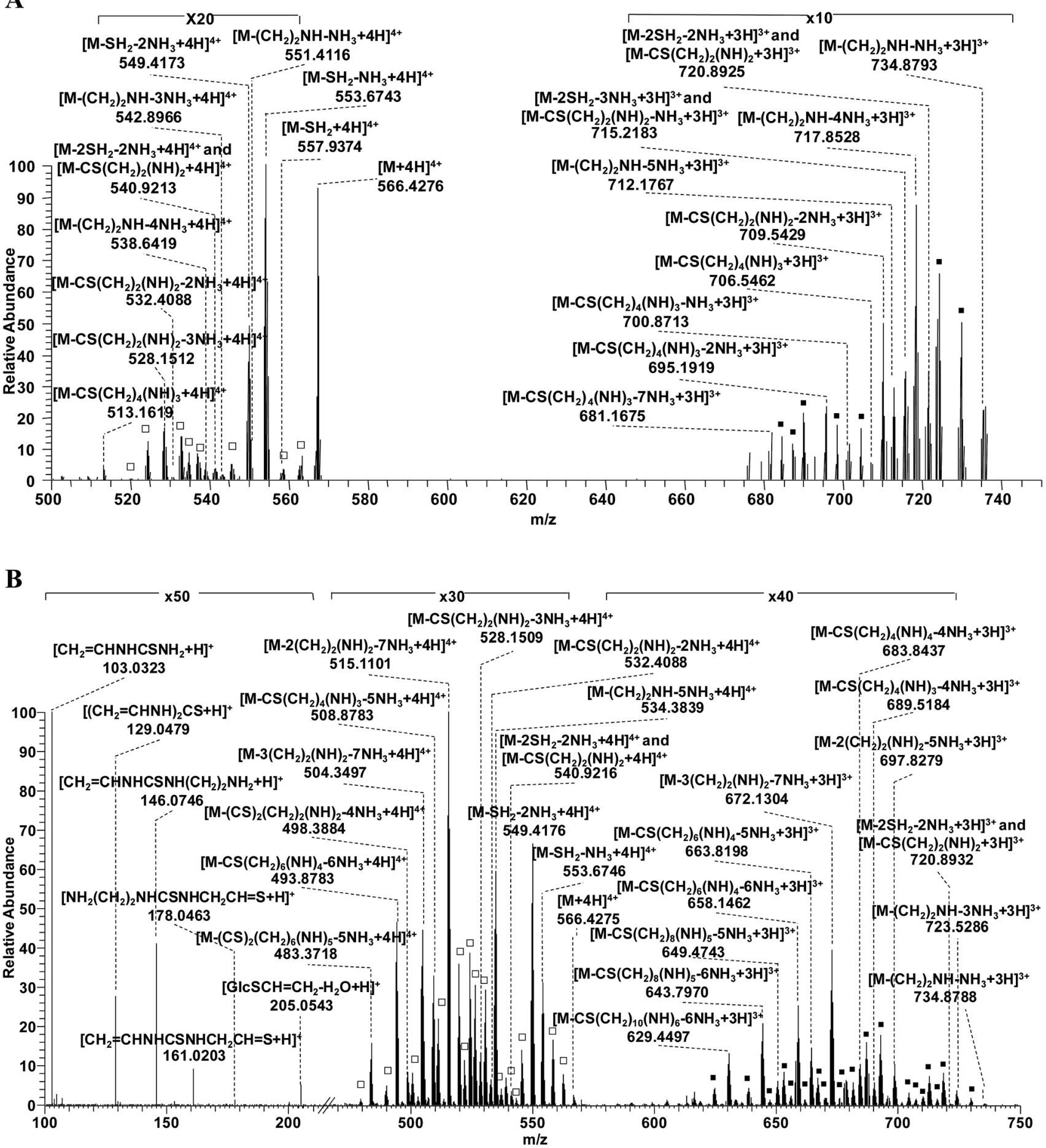

Fig. 6 MS/MS spectra obtained for fragmentation of $[M+4 H]^{4+}$ of agent 3 in $\mathrm{CID}(\mathrm{A})$ and $\mathrm{HCD}(\mathrm{B})$. NH 3 loss at the precursor ( $\square$ ) and lower ( charge states; $\mathrm{H}_{2} \mathrm{O}$ loss at the precursor $(\diamond)$ and lower $(\diamond)$ charge states. 
$\left.\mathrm{CS}\left(\mathrm{CH}_{2}\right)_{2}(\mathrm{NH})_{2}+3 \mathrm{H}\right]^{3+}$ and for $\left[\mathrm{M}-\mathrm{CS}\left(\mathrm{CH}_{2}\right)_{2}(\mathrm{NH})_{2}+4 \mathrm{H}\right]^{4+}$, respectively) or $\mathrm{CS}\left(\mathrm{CH}_{2}\right)_{4}(\mathrm{NH})_{3}$ (e.g. $\mathrm{m} / \mathrm{z} 706.5462$ and for $\mathrm{m} / \mathrm{z}$ 513.1619 for $\left[\mathrm{M}-\mathrm{CS}\left(\mathrm{CH}_{2}\right)_{4}(\mathrm{NH})_{3}+3 \mathrm{H}\right]^{3+}$ and for $[\mathrm{M}-$ $\left.\mathrm{CS}\left(\mathrm{CH}_{2}\right)_{4}(\mathrm{NH})_{3}+4 \mathrm{H}\right]^{4+}$, respectively). Unfortunately, here it was not possible to unambiguously ascribe the cleavage sites since it can occur by rupture of unique grafted arms $\left(-\mathrm{NH}_{2}\left(\mathrm{CH}_{2}\right)_{2}\right.$ $\mathrm{NHCSNH}\left(\mathrm{CH}_{2}\right)_{2}+\mathrm{H}$ ) or two distinct ones (on one hand: $-\mathrm{NH}_{2}\left(\mathrm{CH}_{2}\right)_{2} \mathrm{NHCS}+\mathrm{H}$ and on the other hand $\left.-\mathrm{NH}_{2}\left(\mathrm{CH}_{2}\right)_{2}+\mathrm{H}\right)$. Another particular fragmentation from the thioureidocystenaminyl moiety is the loss of $\mathrm{SH}_{2},(-33.961$ mass units), due to internal cyclization of the $-\mathrm{NHCSNH}\left(\mathrm{CH}_{2}\right)_{2}(\mathrm{NH})_{2}$ chain leading to a five membered ring (ESI Fig. S2 $\dagger$ ). Moreover, for such an agent, neither water loss nor glycosidic cleavage was detected. This was presumably due to a total dissipation of CID energy along thioureidocystenaminyl arms before reaching the CD scaffold. Using higher collision dissociation, the MS/MS spectrum clearly depicted more ions than upon CID, including those observed and newly formed (Fig. 6B). This richer spectrum both in $4+$ and $3+$ ions portrays the more deeply sequential fragmentation of a given thioureidocystenaminyl arm, for example with ions at $m / z 562.1712\left(\left[\mathrm{M}-\mathrm{NH}_{3}+4 \mathrm{H}\right]^{4+}\right)$, $m / z 734.8788\left(\left[\mathrm{M}-\left(\mathrm{CH}_{2}\right)_{2} \mathrm{NH}-\mathrm{NH}_{3}+3 \mathrm{H}\right]^{3+}\right), m / z 540.9216([\mathrm{M}$ $\left.\left.-\mathrm{CS}\left(\mathrm{CH}_{2}\right)_{2}(\mathrm{NH})_{2}+4 \mathrm{H}\right]^{4+}\right)$ and $m / z 508.8783\left(\left[\mathrm{M}-\mathrm{CS}\left(\mathrm{CH}_{2}\right)_{4}(-\right.\right.$ $\left.\left.\mathrm{NH})_{3}-5 \mathrm{NH}_{3}+3 \mathrm{H}\right]^{3+}\right)$. Such fragmentation allowed for reaching only the thioether cleavage on one side forming a thiol moiety which remains anchored to a glucose unit.

Nevertheless, HCD deposited energy affects also simultaneously the other close arms. Indeed, if the energy level is higher to gain insight to a given one, it can also be enough to begin breakdown of another backbone. As example $\mathrm{m} / z 720.893$ and 540.921 represent losses of $\mathrm{CS}\left(\mathrm{CH}_{2}\right)_{2}(\mathrm{NH})_{2}$ and $\mathrm{SH}_{2}-2 \mathrm{NH}_{3}$ under $3+$ and $4+$ charge states (Fig. 6A), respectively, as evidenced by an isotopic cluster (data not shown), revealing that cyclization occurred on two distinct backbones. Other examples can be cited representing only extremities before one CS bond, at $m / z 697.828\left(\left[\mathrm{M}-2\left(\mathrm{CH}_{2}\right)_{2}(\mathrm{NH})_{2}-5 \mathrm{NH}_{3}+3 \mathrm{H}\right]^{3+}\right), m / z 672.130$ $\left(\left[\mathrm{M}-3\left(\mathrm{CH}_{2}\right)_{2}(\mathrm{NH})_{2}-7 \mathrm{NH}_{3}+3 \mathrm{H}\right]^{3+}\right), 515.110([\mathrm{M}-$ $\left.\left.2\left(\mathrm{CH}_{2}\right)_{2}(\mathrm{NH})_{2}-7 \mathrm{NH}_{3}+4 \mathrm{H}\right]^{4+}\right)$ and $\mathrm{m} / \mathrm{z} 504.349([\mathrm{M}$ $\left.\left.3\left(\mathrm{CH}_{2}\right)_{2}(\mathrm{NH})_{2}-7 \mathrm{NH}_{3}+4 \mathrm{H}\right]^{4+}\right)$, including both one $\mathrm{CS}$ bond and another end extremity(ies) for examples at $m / z 663.3819$ ([M $\left.\left.\mathrm{CS}-\left(\mathrm{CH}_{2}\right)_{6}(\mathrm{NH})_{4}-5 \mathrm{NH}_{3}+3 \mathrm{H}\right]^{3+}\right), m / z 649.474([\mathrm{M}-\mathrm{CS}-$ $\left.\left.\left(\mathrm{CH}_{2}\right)_{8}(\mathrm{NH})_{5}-5 \mathrm{NH}_{3}+3 \mathrm{H}\right]^{3+}\right), m / z 629.449([\mathrm{M}-\mathrm{CS}-$ $\left.\left.\left(\mathrm{CH}_{2}\right)_{10}(\mathrm{NH})_{6}-6 \mathrm{NH}_{3}+3 \mathrm{H}\right]^{3+}\right)$ and $m / z 493.878([\mathrm{M}-\mathrm{CS}-$ $\left.\left.\left(\mathrm{CH}_{2}\right)_{6}(\mathrm{NH})_{4}-6 \mathrm{NH}_{3}+4 \mathrm{H}\right]^{4+}\right)$ or after two CS bonds for example at $m / z 498.388\left(\left[\mathrm{M}-(\mathrm{CS})_{2}-\left(\mathrm{CH}_{2}\right)_{2}(\mathrm{NH})_{2}-4 \mathrm{NH}_{3}+4 \mathrm{H}\right]^{4+}\right)$ and $m / z 483.371\left(\left[\mathrm{M}-(\mathrm{CS})_{2}-\left(\mathrm{CH}_{2}\right)_{6}(\mathrm{NH})_{5}-5 \mathrm{NH}_{3}+4 \mathrm{H}\right]^{4+}\right)$. This can represent an advantage in the case of a non permodification, with a rather regioselective one. Thanks to the HCD mode which allowed for the by-pass of the low mass cutoff, additional low intensity ions are observed. One ion at $\mathrm{m} / \mathrm{z}$ 205.0543 corresponding to a truncated form of one building block [GlcSCH $\left.=\mathrm{CH}_{2}-\mathrm{H}_{2} \mathrm{O}-\mathrm{H}\right]^{+}$(Fig. $6 \mathrm{~B}$ ) could be assigned to i.e. $\left[\mathrm{C}_{7} / \mathrm{Z}_{1}-\mathrm{CSNH}\left(\mathrm{CH}_{2}\right)_{4}(\mathrm{NH})_{3}+\mathrm{H}\right]^{+}$but no remaining complementary pieces have been detected. On the other hand, lower mass ions corresponding to a free moiety from thioureidocystenaminyl were noted at $m / z$ 178.046 $\left(\left[\mathrm{NH}_{2}\right.\right.$ $\left.\left.\left(\mathrm{CH}_{2}\right)_{2} \mathrm{NHCS}-\mathrm{NHCH}_{2} \mathrm{CH}=\mathrm{S}+\mathrm{H}\right]^{+}\right)$, at $m / z 161.020\left(\left[\mathrm{CH}_{2}=\right.\right.$
$\left.\left.\mathrm{CHNHCSNHCH}_{2} \mathrm{CH}=\mathrm{S}+\mathrm{H}\right]^{+}\right), \quad m / z \quad 146.075 \quad\left(\left[\mathrm{CH}_{2}=\right.\right.$ $\left.\left.\mathrm{CHNHCSNH}\left(\mathrm{CH}_{2}\right)_{2} \mathrm{NH}_{2}+\mathrm{H}\right]^{+}\right), \quad m / z \quad 129.048 \quad\left(\left[\mathrm{CH}_{2}=\right.\right.$ $\left.\left.\mathrm{CHNHCSNHCH}=\mathrm{CH}_{2}+\mathrm{H}\right]^{+}\right)$and $m / z$ 103.032 $\left(\left[\mathrm{CH}_{2}=\right.\right.$ $\left.\mathrm{CHNHCSNH}_{2}+\mathrm{H}\right]^{+}$).

Upon CID fragmentation, the most intense ion of agent 4, the quadruply charged, gives fewer fragments under the same precursor charge states than under a lower one $(3+)$ (Fig. 7A). Among ions, some can be ascribed to the loss of $\left(\mathrm{CH}_{2}\right)_{2}(\mathrm{NH})_{2}$ (e.g. $m / z 626.735$ for $\left.\left[\mathrm{M}-\left(\mathrm{CH}_{2}\right)_{2}(\mathrm{NH})_{2}+4 \mathrm{H}\right]^{4+}\right),\left(\mathrm{CH}_{2}\right)_{4}(\mathrm{NH})_{2}-$ $\mathrm{NH}_{3}$ (e.g. $m / z 820.964$ for $\left[\mathrm{M}-\left(\mathrm{CH}_{2}\right)_{2}(\mathrm{NH})_{2}-\mathrm{NH}_{3}+3 \mathrm{H}\right]^{3+}$, $\left.\mathrm{CS}\left(\mathrm{CH}_{2}\right)_{4}(\mathrm{NH})_{3}\right)($ e.g. $\mathrm{m} / \mathrm{z} 806.976$ and $\mathrm{m} / \mathrm{z} 605.486$ for $[\mathrm{M}-$ $\left.\mathrm{CS}\left(\mathrm{CH}_{2}\right)_{4}(\mathrm{NH})_{3}+3 \mathrm{H}\right]^{3+}$ and $\left[\mathrm{M}-\mathrm{CS}\left(\mathrm{CH}_{2}\right)_{4}(\mathrm{NH})_{3}+4 \mathrm{H}\right]^{4+}$, respectively) and also a further series of $\mathrm{CS}\left(\mathrm{CH}_{2}\right)_{n}(\mathrm{NH})_{m}$ with the $n / m$ ratio varying as $6 / 4,8 / 5,8 / 6$ and $10 / 7$ with additional ammoniac loss $(\mathrm{m} / \mathrm{z} 786.955$ to $\mathrm{m} / \mathrm{z}$ 738.600). The higher occurrence of a secondary amine along the aminoethylthioureidocystenaminyl moiety increases the number of sites of protonation and consequently favors bond breakdown, notably in the neighbour of CS groups involving mainly charge reduction (here from $4+$ to $3+$ ) consecutive to the fragmentation process. Nonetheless, such site driven charge locations impair homogeneous fragmentation along the structure, which considerably reduced the fragmentation yield. Similar precursors upon HCD led to fewer and similar ions compared to CID (Fig. 7B). Some exceptions occurred with the detection of ions at $m / z 615.973$ corresponding to $\left[\mathrm{M}-\left(\mathrm{CH}_{2}\right)_{4}(\mathrm{NH})_{2}-\mathrm{NH}_{3}+4 \mathrm{H}\right]^{4+}$ and as observed for agent 3, of ions at $m / z 146.075$ and $\mathrm{m} / z$ 129.048 relative to $\left[\mathrm{CH}_{2}=\mathrm{CHNHCSNH}\left(\mathrm{CH}_{2}\right)_{2} \mathrm{NH}_{2}+\mathrm{H}\right]^{+}$and $\left[\mathrm{CH}_{2}=\mathrm{CHNHCSNHCH}=\mathrm{CH}_{2}+\mathrm{H}\right]^{+}$, respectively.

Dissociation of agent 5 yields to the lower fragmentation yield $\left(\approx 10-15 \%\right.$ at the $\mathrm{CE}_{50}$ value) where the CID MS/MS spectrum shows mainly ions resulting from only ammoniac losses (e.g. $m / z 736.4580$ or $m / z 732.2037$ for $\left[\mathrm{M}-2 \mathrm{NH}_{3}+4 \mathrm{H}\right]^{4+}$ and $\left.\left[\mathrm{M}-3 \mathrm{NH}_{3}+4 \mathrm{H}\right]^{4+}\right)$, and loss of $\mathrm{CS}\left(\mathrm{CH}_{2}\right)_{2}(\mathrm{NH})_{2}$ with or without ammoniac loss (e.g. $m / z 953.2757$ or $m / z 719.4657$ for [M $\left.-\mathrm{CS}\left(\mathrm{CH}_{2}\right)_{2}(\mathrm{NH})_{2}-\mathrm{NH}_{3}+3 \mathrm{H}\right]^{3+}$ and $\left[\mathrm{M}-\mathrm{CS}\left(\mathrm{CH}_{2}\right)_{2}(\mathrm{NH})_{2}+\right.$ $4 \mathrm{H}^{4+}$ ) (Fig. 8A). Contrary to agent 4 , most products are under the same charge states $(4+)$ compared to the precursor. Interestingly, in spite of the presence of the dithioureidocystenaminyl moiety, the internal cyclization (loss of $\mathrm{SH}_{2}$ ) did not occur. This may be due to rigidity of longer arms as compared to the simple thioureidocystenaminyl one (agent 3). Higher dissociation tuning on the precursor only led to detection of low mass fragments depicting free pieces of dithioureidocystenaminyl as highlighted by four ions at $\mathrm{m} / \mathrm{z} 188.031$ $\left(\left[\mathrm{CH}_{2}=\mathrm{CHNHCSNH}\left(\mathrm{CH}_{2}\right)_{2} \mathrm{NCS}+\mathrm{H}\right]^{+}\right), m / z$ 146.074 $\left(\left[\mathrm{CH}_{2}=\right.\right.$ $\left.\left.\mathrm{CHNHCSNH}\left(\mathrm{CH}_{2}\right)_{2} \mathrm{NH}_{2}+\mathrm{H}\right]^{+}\right), \quad m / z \quad 129.048 \quad\left(\left[\mathrm{CH}_{2}=\right.\right.$ $\left.\left.\mathrm{CHNHCSNHCH}=\mathrm{CH}_{2}+\mathrm{H}\right]^{+}\right)$, and $m / z$ 103.032 $\left(\left[\mathrm{CH}_{2}=\right.\right.$ $\left.\mathrm{CHNHCSNH}_{2}+\mathrm{H}\right]^{+}$) (Fig. 8B).

\subsection{Straightforward structural deciphering-activity relationship}

Selection of an efficient agent for interaction with RNA/DNA leading to optimal compaction and then efficient vectorisation requires the control of synthesised architectures. The usual way used to define the balance between polycationic and RNA/ 

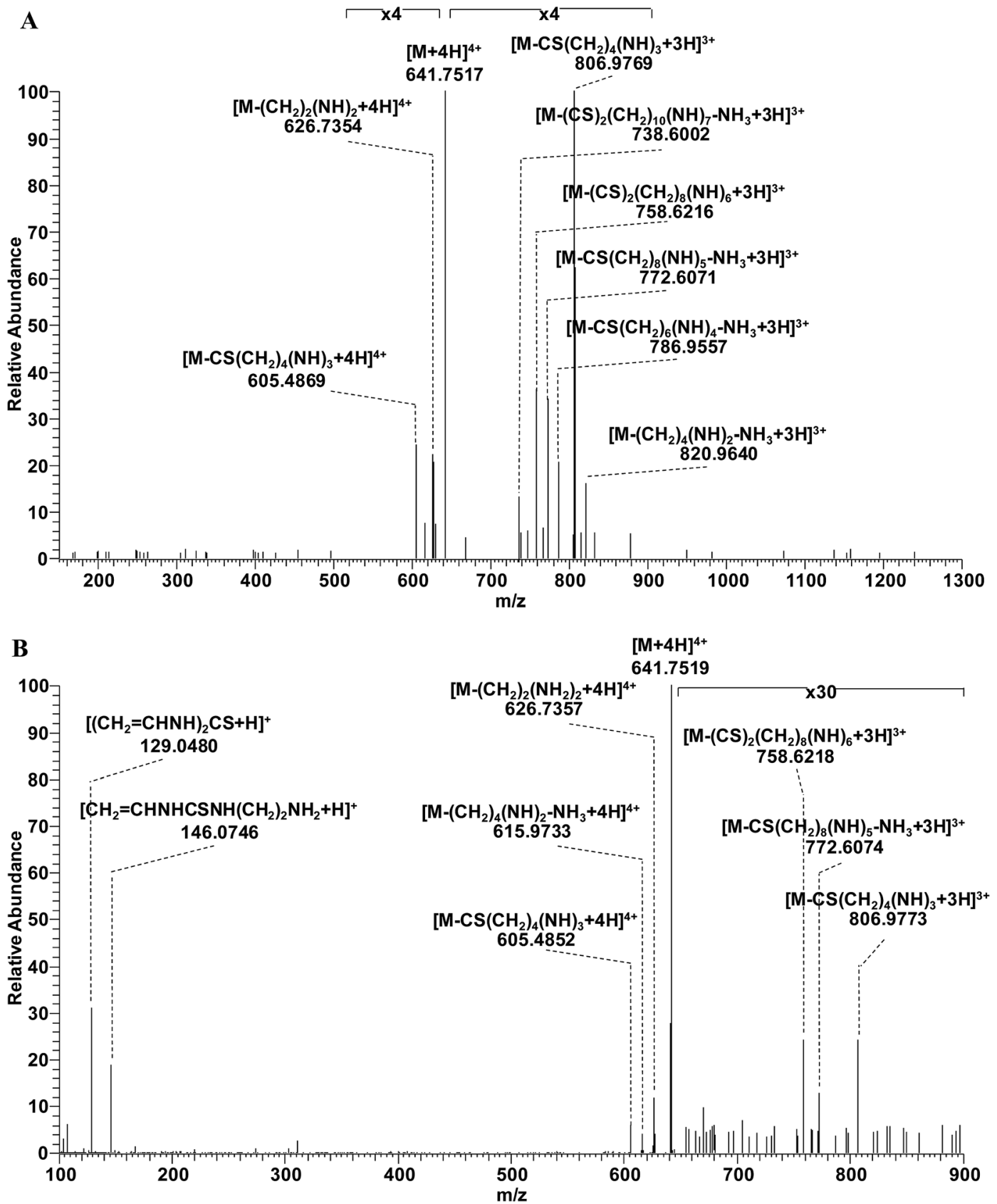

Fig. $7 \mathrm{MS} / \mathrm{MS}$ spectra obtained for fragmentation of $[\mathrm{M}+4 \mathrm{H}]^{4+}$ of agent 4 in $\mathrm{CID}(\mathrm{A})$ and $\mathrm{HCD}(\mathrm{B})$. $\mathrm{NH}_{3}$ loss at the precursor ( $\square$ ) and lower ( charge states; $\mathrm{H}_{2} \mathrm{O}$ loss at the precursor $(\diamond)$ and lower $(\diamond)$ charge states.

DNA molecules is the nitrogen/phosphorus ratio $(\mathrm{N} / \mathrm{P}$ ratio) corresponding to the amino groups of the vectorisation agent and the phosphate moiety of the nucleobases. However, other criteria must be considered such as the nature of amino groups (primary, secondary or ternary) as well as their location within the potential vector. For example, we can cite some features highlighted elsewhere like the effects of block versus statistical glycopolycation containing primary and tertiary amines, ${ }^{\mathbf{6}}$ amide spacing in poly(amidoamine)s, ${ }^{\mathbf{1 4}}$ and the role of the polymer length, ${ }^{67}$ carbohydrate size ${ }^{28,67}$ and structural modifications. $^{34}$ In this sense, tandem mass spectrometry is an appropriate tool to address the following question: is the expected structure correct? Efficiency of a straightforward sequencing method(s) is based on its ability to cover most of the chemical functions within agents, and that of the studied architectures. In our case, considering per-6-amino- $\beta$-cyclodextrin (Fig. 9, agent 1), both the glycosidic CD backbone (B/C and $\mathrm{Y} / \mathrm{Z}$ ions) and amino modification $\left(-\mathrm{NH}_{3}\right.$ and $\left.-\mathrm{CHNH}_{2}\right)$ were clearly highlighted.

For per-6-cysteaminyl- $\beta$-cyclodextrin (Fig. 9, agent 2), again both the glycosidic $\mathrm{CD}$ backbone $(\mathrm{B} / \mathrm{C}$ and $\mathrm{Y} / \mathrm{Z}$ ions) and grafted cysteaminyl groups $\left(-\mathrm{NH}_{3},-(\mathrm{CH})_{2} \mathrm{NH}\right.$ and $\left.-\mathrm{S}\left(\mathrm{CH}_{2}\right)_{2} \mathrm{NH}_{3}\right)$ were 
A

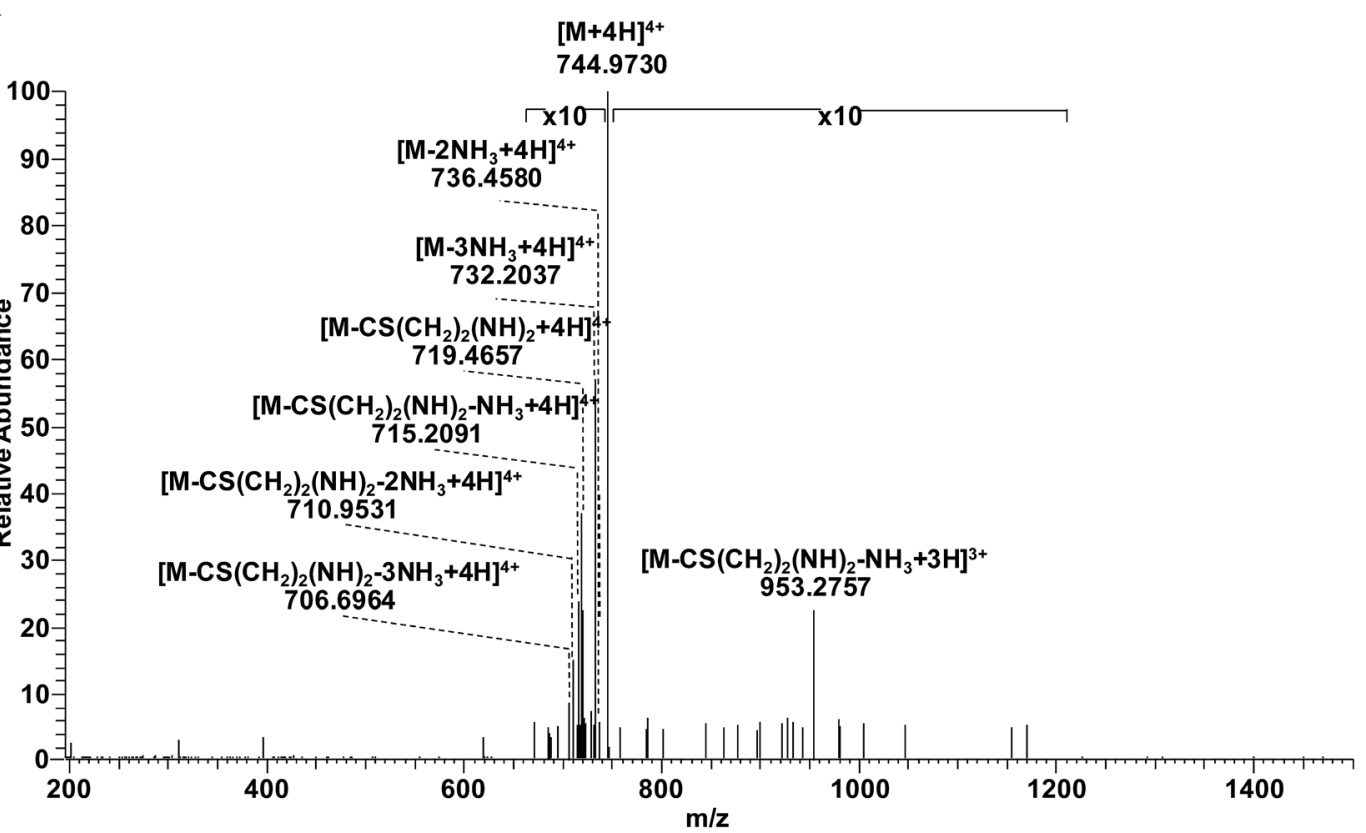

B

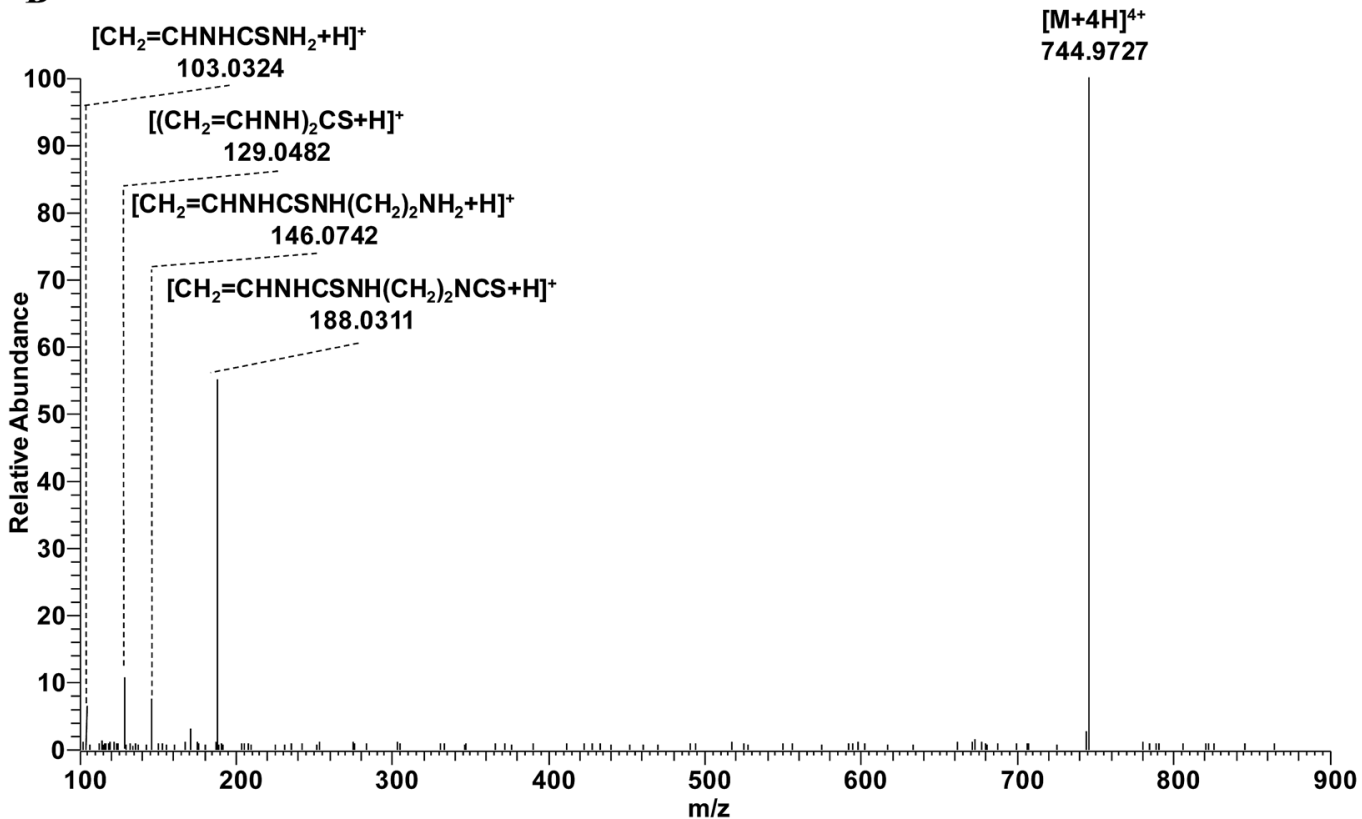

Fig. $8 \mathrm{MS} / \mathrm{MS}$ spectra obtained for fragmentation of $[\mathrm{M}+4 \mathrm{H}]^{4+}$ of agent 5 in $\mathrm{CID}(\mathrm{A})$ and $\mathrm{HCD}(\mathrm{B})$. $\mathrm{NH}_{3}$ loss at the precursor ( $\square$ ) and lower ( charge states; $\mathrm{H}_{2} \mathrm{O}$ loss at the precursor $(\diamond)$ and lower $(\diamond)$ charge states.

covered. It was noted that some intracyclic cleavages $\left({ }^{0,2} \mathrm{~A}\right)$, presumably due to cysteaminyl groups, were also produced. Addition of longer arms on the $\beta$-CD scaffold constituting per-6thioureidocystenaminyl- $\beta$-cyclodextrin (Fig. 9, agent 3), did not allow ions that confirmed the glycosidic scaffold to be obtained any more. On the other hand, complete sequencing can be achieved for the thioureidocystenaminyl moiety $\left(-\mathrm{NH}_{3}\right.$, $-(\mathrm{CH})_{2} \mathrm{NH},-\mathrm{SH}_{2},-\mathrm{CS}\left(\mathrm{CH}_{2}\right)_{2} \mathrm{NH}_{2},-{ }^{2} \mathrm{CS}\left(\mathrm{CH}_{2}\right)_{4} \mathrm{NH}_{3}$ and $-\mathrm{CS}_{2}$ $\left.\left(\mathrm{CH}_{2}\right)_{4}(\mathrm{NH})_{2} \mathrm{NH}_{3}\right)$. As for agent 3, further extension of the cationic anchored linear arm leading to per-6-aminoethylthioureidocysteaminyl- $\beta$-cyclodextrin (Fig. 9, agent 4), did not permit the confirmation of the $\beta$-CD scaffold but also slightly reduced coverage of the aminoethylthioureidocysteaminyl moiety. Indeed, its structural deciphering can only be achieved until one side of the thioether group $\left(-\mathrm{NH}_{3},-\left(\mathrm{CH}_{2}\right)_{2} \mathrm{NH}, \quad-\left(\mathrm{CH}_{2}\right)_{4}(\mathrm{NH})_{2},-{ }^{2} \mathrm{CS}\left(\mathrm{CH}_{2}\right)_{4}(\mathrm{NH})_{3}\right.$, $-\mathrm{CS}\left(\mathrm{CH}_{2}\right)_{4}(\mathrm{NH})_{3} \mathrm{NH}_{3}$ and $\left.-\mathrm{CS}_{2}\left(\mathrm{CH}_{2}\right)_{6}(\mathrm{NH})_{4}\right)$. Adding a second thiourea group forming per-6-dithioureidocysteaminyl- $\beta$-cyclodextrin (Fig. 9, agent 5) lead to the worst overall coverage since only three sections of the dithioureidocysteaminyl moiety were covered $\left(-\mathrm{NH}_{3},-\mathrm{CS}\left(\mathrm{CH}_{2}\right)_{2}(\mathrm{NH})_{2}\right.$, and $\left.-\mathrm{CS}\left(\mathrm{CH}_{2}\right)_{2}(\mathrm{NH})_{2} \mathrm{NH}_{3}\right)$. Together, these results clearly showed that for permodified $\beta$ - 
Agent 1

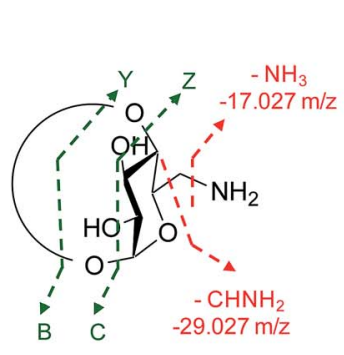

Agent 2

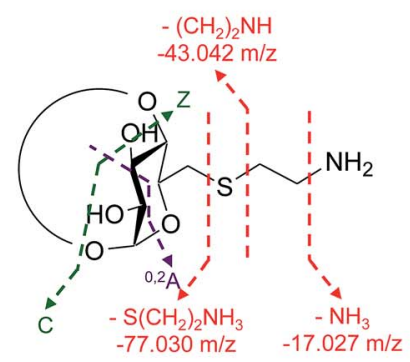

Agent 3

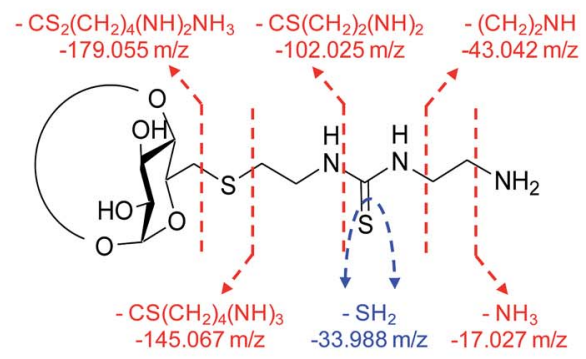

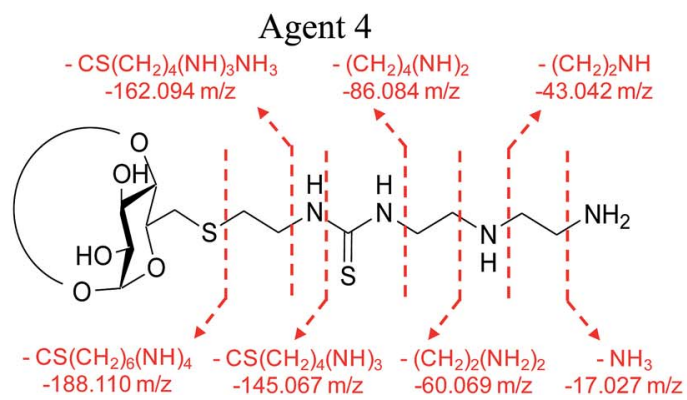

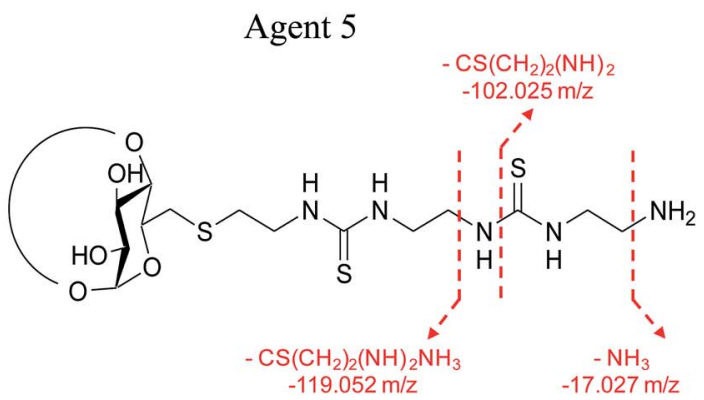

Fig. 9 Summary of experimental losses during MS/MS experiments combining CID/HCD for structural deciphering of agents 1 to 5 . Detailed losses occurring for every agent are given in ESI Fig. S2.†

$\mathrm{CD}$, the glycosidic content and grafted arms can be integrally sequenced by the CDI/HCD pair until the cysteaminylated form. Extension of attached groups to the thioureidocystenaminylated one allows a fully sequencing of this last one while it avoids the scaffold structural confirmation. Further progressive extension of the arm's length yields to a slight and dramatic reduction of fragmentation efficiency for aminoethylthioureidocysteaminyl and dithioureidocysteaminyl, respectively, and consequently lower coverage capacity. The reduction of progressive scaffold determination appeared to be a function of the anchored group extension, and presumably due to fast energy dissipation along and from the end of the thio/amino chain towards the $\beta$-CD core. From our point of view, absence of $\beta$-CD scaffold reporting ions for agents 3 and 4 is not a limiting factor, since the original $\beta$-CD backbone is commercially well defined in terms of structure and purity, and then can be directly used with confidence for further modifications. However, per-dithioureidocysteaminyl- $\beta$-cyclodextrin appeared as the limiting structure for efficient sequencing, in spite of the fine energy tuning purposed by the HCD mode.

\section{Conclusions}

Polycationic agents, especially those exhibiting multiple proton attachment pose severe problems for their intact analysis by MS. These difficulties come from their high propensity for $\mathrm{N}-\mathrm{C}$ bond cleavage in both the solution and gas phase, but also to the high resolutive power requirement with high charge states. During MS analysis, such a phenomenon is also supported by coulombic repulsion strengthened during transfer from solution to the gas phase. In this study, we have successfully demonstrated that some intact carbohydrate based non-viral gene delivery agents carrying several amino/thio groups can be analyzed by ESI-MS and ESI-MS/MS using a CID/HCD combination. Resulting fragmentation patterns in both CID and HCD were related, but sometimes HCD advantageously complements CID, by yielding to very low mass ions (fragments $m / z<1 / 3$ precursor $m / z$ ) which can be useful to establish characteristic "signatures". Some limitations were observed with the larger studied architectures (per-6-dithioureidocysteaminyl- $\beta$ CD) suggesting to us to investigate an alternative dissociation mode such as ETD. However, our reliable approach with the potential to define an exact size, topology (linear, branched, comb, hyperbranched or dendritic), number, and attachment sites of subunits, paves the way for an avenue for analysis of more complex structures such as amphiphilic polycationic carbohydrate derivatives or polycationic polyrotaxanes.

\section{Acknowledgements}

The authors sincerely thank Genopole-France and the Île-deFrance Regional Council for generous financial support.

\section{References}

1 S. Nayak and R. W. Herzog, Gene Ther., 2010, 17, 295-304.

2 E. Marshall, Science, 2000, 288, 951-957.

3 D. W. Pack, A. S. Hoffman, S. Pun and P. S. Stayton, Nat. Rev. Drug Discovery, 2005, 4, 581-593.

4 M. A. Behlke, Mol. Ther., 2006, 13, 644-670.

5 B. Martin, M. Sainlos, A. Aissaoui, N. Oudrhiri, M. Hauchecorne, J.-P. Vigneron, J.-M. Lehn and P. Lehn, Curr. Pharm. Res., 2005, 11, 375-394. 
6 D. Zhi, S. Zhang, S. Cui, Y. Zhao, Y. Wang and D. Zhao, Bioconjugate Chem., 2013, 24, 487-519.

7 C. O. Mellet, J. M. G. Fernandez and J. M. Benito, Chem. Soc. Rev., 2011, 40, 1586-1608.

8 M. A. Mintzer and E. E. Simanek, Chem. Rev., 2009, 109, 259302.

9 D. Putnam, Nat. Mater., 2006, 5, 439-451.

10 O. Boussif, F. Lezoualc'h, M. A. Zanta, M. D. Mergny, D. Scherman, B. Demeneix and J. P. Behr, Proc. Natl. Acad. Sci. U. S. A., 1995, 92, 7297-7301.

11 M. Neu, D. Fischer and T. Kissel, J. Gene Med., 2005, 7, 9921009.

12 T. Bettinger, R. C. Carlisle, M. L. Read, M. Ogris and L. W. Seymour, Nucleic Acids Res., 2001, 29, 3882-3891.

13 S. Agarwal, Y. Zhang, S. Maji and A. Greiner, Mater. Today, 2012, 15, 388-393.

14 L. E. Prevette, M. L. Lynch and T. M. Reineke, Biomacromolecules, 2010, 11, 326-332.

15 W. Khan, H. Hosseinkhani, D. Ickowicz, P.-D. Hong, D.-S. Yu and A. J. Domb, Acta Biomater., 2012, 8, 4224-4232.

16 I. Yudovin-Farber and A. J. Domb, Mater. Sci. Eng., C, 2007, 27, 595-598.

17 S. Toita, N. Morimoto and K. Akiyoshi, Biomacromolecules, 2010, 11, 397-401.

18 C. J. Needham, A. K. Williams, S. A. Chew, F. K. Kasper and A. G. Mikos, Biomacromolecules, 2012, 13, 1429-1437.

19 K. Kim, K. Ryu and T.-i. Kim, Carbohydr. Polym., 2014, 110, 268-277.

20 A. Sizovs, P. M. McLendon, S. Srinivasachari and T. M. Reineke, Carbohydrate Polymers for Nonviral Nucleic Acid Delivery, in Nucleic Acid Transfection, ed. W. Bielke and C. Erbacher, Springer, Berlin, Heidelberg, 2010, vol. 296, pp. 131-190.

21 A. W. Tong, C. M. Jay, P. B. Maples and J. Nemunaitis, Curr. Gene Ther., 2009, 9, 45-60.

22 C. Ortiz Mellet, J. M. Benito and J. M. García Fernández, Chem.-Eur. J., 2010, 16, 6728-6742.

23 M. Giuliani, I. Morbioli, F. Sansone and A. Casnati, Chem. Commun., 2015, 51, 14140-14159.

24 R. V. Rodik, A.-S. Anthony, V. I. Kalchenko, Y. Mely and A. S. Klymchenko, New J. Chem., 2015, 39, 1654-1664.

25 Y. Chang, K. Yang, P. Wei, S. Huang, Y. Pei, W. Zhao and Z. Pei, Angew. Chem., Int. Ed., 2014, 53, 13126-13130.

26 L. Gallego-Yerga, L. Blanco-Fernández, K. Urbiola, T. Carmona, G. Marcelo, J. M. Benito, F. Mendicuti, C. Tros de Ilarduya, C. Ortiz Mellet and J. M. García Fernández, Chem.-Eur. J., 2015, 21, 12093-12104.

27 M. Gooding, M. Malhotra, D. J. McCarthy, B. M. D. C. Godinho, J. F. Cryan, R. Darcy and C. M. O'Driscoll, Eur. J. Pharm. Sci., 2015, 71, 80-92.

28 C. Bienvenu, A. Martinez, J. L. Jimenez Blanco, C. Di Giorgio, P. Vierling, C. Ortiz Mellet, J. Defaye and J. M. Garcia Fernandez, Org. Biomol. Chem., 2012, 10, 5570-5581.

29 M. E. Davis, J. E. Zuckerman, C. H. J. Choi, D. Seligson, A. Tolcher, C. A. Alabi, Y. Yen, J. D. Heidel and A. Ribas, Nature, 2010, 464, 1067-1070.
30 A. M. O’Mahony, B. M. D. C. Godinho, J. Ogier, M. Devocelle, R. Darcy, J. F. Cryan and C. M. O'Driscoll, ACS Chem. Neurosci., 2012, 3, 744-752.

31 E. M. Aguilar Moncayo, N. Guilloteau, C. Bienvenu, J. L. Jimenez Blanco, C. Di Giorgio, P. Vierling, J. M. Benito, C. Ortiz Mellet and J. M. Garcia Fernandez, New J. Chem., 2014, 38, 5215-5225.

32 A. Mendez-Ardoy, M. Gomez-Garcia, C. O. Mellet, N. Sevillano, M. Dolores Giron, R. Salto, F. SantoyoGonzalez and J. M. Garcia Fernandez, Org. Biomol. Chem., 2009, 7, 2681-2684.

33 A. Diaz-Moscoso, P. Balbuena, M. Gomez-Garcia, C. Ortiz Mellet, J. M. Benito, L. Le Gourrierec, C. Di Giorgio, P. Vierling, A. Mazzaglia, N. Micali, J. Defaye and J. M. Garcia Fernandez, Chem. Commun., 2008, 2001-2003.

34 A. Díaz-Moscoso, L. Le Gourriérec, M. Gómez-García, J. M. Benito, P. Balbuena, F. Ortega-Caballero, N. Guilloteau, C. Di Giorgio, P. Vierling, J. Defaye, C. Ortiz Mellet and J. M. García Fernández, Chem.-Eur. J., 2009, 15, 12871-12888.

35 F. Ortega-Caballero, C. O. Mellet, L. Le Gourriérec, N. Guilloteau, C. Di Giorgio, P. Vierling, J. Defaye and J. M. García Fernández, Org. Lett., 2008, 10, 5143-5146.

36 A. Méndez-Ardoy, N. Guilloteau, C. Di Giorgio, P. Vierling, F. Santoyo-González, C. Ortiz Mellet and J. M. García Fernández, J. Org. Chem., 2011, 76, 5882-5894.

37 V. Villari, A. Mazzaglia, R. Darcy, C. M. O'Driscoll and N. Micali, Biomacromolecules, 2013, 14, 811-817.

38 N. Mourtzis, K. Eliadou, C. Aggelidou, V. Sophianopoulou, I. M. Mavridis and K. Yannakopoulou, Org. Biomol. Chem., 2007, 5, 125-131.

39 S.-A. Cryan, A. Holohan, R. Donohue, R. Darcy and C. M. O’Driscoll, Eur. J. Pharm. Sci., 2004, 21, 625-633.

40 N. Mourtzis, M. Paravatou, I. M. Mavridis, M. L. Roberts and K. Yannakopoulou, Chem.-Eur. J., 2008, 14, 4188-4200.

41 S. Srinivasachari, K. M. Fichter and T. M. Reineke, J. Am. Chem. Soc., 2008, 130, 4618-4627.

42 M. J. Kailemia, L. R. Ruhaak, C. B. Lebrilla and I. J. Amster, Anal. Chem., 2014, 86, 196-212.

43 Y. Xie, K. M. Schubothe and C. B. Lebrilla, Anal. Chem., 2003, 75, 160-164.

44 J. T. Adamson and K. Håkansson, Anal. Chem., 2007, 79, 2901-2910.

45 L. Han and C. Costello, J. Am. Soc. Mass Spectrom., 2011, 22, 997-1013.

46 J. R. Kornacki, J. T. Adamson and K. Håkansson, J. Am. Soc. Mass Spectrom., 2012, 23, 2031-2042.

47 B. J. Ko and J. S. Brodbelt, Anal. Chem., 2011, 83, 8192-8200. 48 C. Przybylski, V. Bonnet and C. Cezard, Phys. Chem. Chem. Phys., 2015, 17, 19288-19305.

49 C. Przybylski and V. Bonnet, Rapid Commun. Mass Spectrom., 2013, 27, 75-87.

50 A. Gadelle and J. Defaye, Angew. Chem., Int. Ed., 1991, 30, 7880.

51 B. Domon and C. E. Costello, Glycoconjugate J., 1988, 5, 397409. 
52 M. T. Cancilla, S. G. Penn, J. A. Carroll and C. B. Lebrilla, J. Am. Chem. Soc., 1996, 118, 6736-6745.

53 Z. Zhou, S. Ogden and J. A. Leary, J. Org. Chem., 1990, 55, 5444-5446.

54 L. C. Ngoka, J. F. Gal and C. B. Lebrilla, Anal. Chem., 1994, 66, 692-698.

55 T. R. Covey, R. F. Bonner, B. I. Shushan, J. Henion and R. K. Boyd, Rapid Commun. Mass Spectrom., 1988, 2, 249-256.

56 A. T. Iavarone, J. C. Jurchen and E. R. Williams, J. Am. Soc. Mass Spectrom., 2000, 11, 976-985.

57 B. L. Schwartz, A. L. Rockwood, R. D. Smith, D. A. Tomalia and R. Spindler, Rapid Commun. Mass Spectrom., 1995, 9, 1552-1555.

58 L. P. Tolić, G. A. Anderson, R. D. Smith, H. M. Brothers Ii, R. Spindler and D. A. Tomalia, Int. J. Mass Spectrom., 1997, 165-166, 405-418.

59 J. Fernandez de la Mora, Anal. Chim. Acta, 2000, 406, 93-104.
60 J. B. Fenn, J. Am. Soc. Mass Spectrom., 1993, 4, 524-535.

61 V. J. Nesatyy and M. J. F. Suter, J. Mass Spectrom., 2004, 39, 93-97.

62 A. Nasioudis, A. Memboeuf, R. M. A. Heeren, D. F. Smith, K. Vékey, L. Drahos and O. F. van den Brink, Anal. Chem., 2010, 82, 9350-9356.

63 A. Memboeuf, A. Nasioudis, S. Indelicato, F. Pollreisz, Á. Kuki, S. Kéki, O. F. van den Brink, K. Vékey and L. Drahos, Anal. Chem., 2010, 82, 2294-2302.

64 P. Neta, Y. Simon-Manso, X. Yang and S. E. Stein, J. Am. Soc. Mass Spectrom., 2009, 20, 469-476.

65 E. L. Zins, C. Pepe and D. Schroder, J. Mass Spectrom., 2010, 45, 1253-1260.

66 D. Sprouse and T. M. Reineke, Biomacromolecules, 2014, 15, 2616-2628.

67 L. Xue, N. P. Ingle and T. M. Reineke, Biomacromolecules, 2013, 14, 3903-3915. 